\title{
Ómagyar kori helynévmintázatok a Zsitva völgyében*
}

1. Néhány korábbi dolgozatomban a Bakonyalja ómagyar kori nyelvi viszonyait vettem vizsgálat alá (HOFFMANN 2017a, 2017b, összefoglaló igénnyel 2019), egyrészt azzal a céllal, hogy az ott megjelenő nyelvek konkrét időbeli és térbeli helyzetét elemezzem a térség helynévrendszerének segítségével, de másrészt ezen keresztül - egy új típusú módszertan megalkotásának a szándékával is. Úgy vélem ugyanis, hogy az a vizsgálati mód, amely elsősorban MELICH JÁNOS (1925-1929) és KNIEZSA ISTVÁN (1938) eljárására alapozva máig használatban van — noha kritikák sorában részesült —, nem alkalmas a Kárpát-medence régi nyelvi viszonyainak reális ábrázolására. Az etimológiai elemzésen és a helynevek kormeghatározó értékének elméletén alapuló metódus helyébe a helynév-rekonstrukciót, illetőleg a helynevek relatív kronológiájának vizsgálatát célszerü helyezni, mégpedig nem egy valamilyen szempont alapján megrostált, kronológiai tekintetben szükített névanyagra vonatkozóan, hanem az adott térség névkincsének minél nagyobb részét bevonva az elemzésbe. E módszerek előnyeiről itt nem szólok ismételten, mivel fent említett munkáimban az erre vonatkozó érveket bemutattam (ehhez lásd még HOFFMANN-TóTH 2016, valamint HOFFMANN-RÁCZTóTH 2018: 135-147, 183-185).

A bakonyalji térség nyelvi viszonyainak elemzését öt kisebb folyóvíz völgyét érintően végeztem el, s rajzoltam meg ezek alapján egy olyan nyelvi, illetve helynévmintázatot - felvázolva ennek feltehető történeti hátterét is - , amely megítélésem szerint más térségekben is érvényes lehet.

Ebben a tanulmányban az analízist a Zsitva völgyére vonatkozóan kívánom elvégezni azzal a céllal, hogy a térség nyelvi mintázatát az ómagyar kori helynévkincs alapján megrajzoljam. A korábbi vizsgálati helyszínhez képest hasonlóságok és különbözőségek is mutatkoznak a természetföldrajzi környezetet illetően: a Zsitvához hasonlóan a bakonyalji folyók is hegyes, dombos vidékről indulva alföldi jellegü térségen folynak tovább, de folyásuk jóval rövidebb a Zsitváénál: csupán a fele-harmada annak. Különbség továbbá az is, hogy az itt vizsgálandó térség korai ómagyar kori (lényegében Árpád-kori) történetének és ezzel együtt helynévanyagának a feltárása sokkal alaposabban megtörtént, elsősorban GYÖRFFY

\footnotetext{
* A tanulmány az MTA-DE Magyar Nyelv- és Névtörténeti Kutatócsoport programja keretében és az NKFI 128270. számú pályázat támogatásával készült.
} 
GYÖRGY történeti földrajzának érdeméből (Gy. 1-4). Így a korábbinál jóval gazdagabb, korszerüen feldolgozott adatállományra támaszkodhattam, s nem csupán a településnevekére, hanem a mikrotoponimákéra is.

2. A Zsitva az egykori Bars vármegyében a Tribecs hegység $400 \mathrm{~m}$ feletti térségében ered, mintegy 20 km hosszú első szakaszán erdős hegyek között folyt, és folyik jórészt ma is. A völgye Marótnál kezd kiszélesedni, mintegy 180-200 mes tengerszint feletti magasságban, dombos, hullámos felszínü területen. A hegyés a dombvidéken gazdag mellékvízrendszere van, e patakok hosszúsága azonban a $10 \mathrm{~km}-\mathrm{t}$ is csak ritkán haladja meg. Az utolsó jelentősebb mellékfolyás, a Rohozsnica Verebélynél érte el a folyót. Ebben a térségben a vízgyüijtő területe nyugati mellékfolyásai révén átnyúlt Nyitra vármegyébe is. Ettől délre a Zsitva alföldi jellegü sík területen haladt tovább Bars, majd Komárom vármegyében, 140 mnél alacsonyabb térségben. A Dunát (Duna)Almás településsel szemben, Zsitvatőnél $107 \mathrm{~m}$ tengerszint feletti magasságban érte el. Ez az alsó szakasza az újabb kori vízszabályozások következtében erősen módosult. A Zsitva egész folyáshossza egykor mintegy $120 \mathrm{~km}$ lehetett, amelynek utolsó két harmadán minimális volt a folyó vizének esése. E szakasz jó részét kiterjedt mocsarak kísérték, különösen ott, ahol - Gyalla, Mercse térségében - megközelíti a Nyitrát. Ez a mocsaras vidék a 18-19. század katonai térképein $(\mathrm{K} 1, \mathrm{~K} 2)$ jól kivehető, mint ahogyan az is, hogy a Zsitva vizét itt részben felvette a nála bővebb vizü Nyitra. GYÖRFFY GYÖRGY szerint a folyónak ez a lefolyása már a 13. századtól meglehetett (Gy. 3: 388). Ebben az alföldi jellegü térségben a Zsitvának csak jelentéktelen mellékvizei voltak (lásd ehhez az 1. ábrát).

A folyó völgyének helynévállományát erre a térségre kiterjedően vizsgálom, döntően GYÖRFFY GYÖRGY történeti földrajza megfelelő fejezeteinek idevágó adatai alapján (Gy. 1: 411-489, Gy. 3: 383-465, Gy. 4: 323-493). Munkámat jelentősen segítette, hogy Bars vármegye teljes korai ómagyar kori helynévanyagát TÓTH VALÉRIA a közelmúltban mind etimológiai, mind pedig nyelv- és névtörténeti szempontból igen alaposan feltárta (2001a, 2001b).

A Zsitva folyó neve minden kétséget kizáróan szláv eredetü. Legkorábbi előfordulásai még eredeti szláv alakját mutatják: 1075/+1124/+1217: Sitoua, +1124/ +1217/1328: Sytoua, [1165 k.]: Sitouna (KMHsz. 1: 307), és [zsitova] ejtésre utalnak. Az etimológiai irodalom egyöntetü állásfoglalása szerint a víznév az ös-

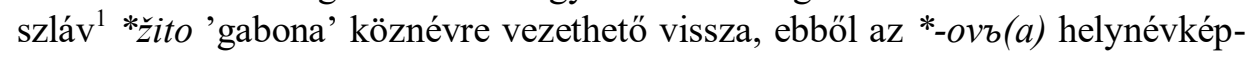
zővel jött létre (MELICH 1925-1929: 351, FNESz., KISS L. 1999: 83). A *žito

\footnotetext{
${ }^{1}$ A szláv nyelvtörténeti szakirodalomban használt összláv nyelv terminus értelmezése és kronológiája nem egységes, s ebből adódóan többféle felfogás létezik az egyes szláv nyelvek kialakulásával kapcsolatban is (vö. ZOLTÁN 2015: 36-37). Ennek tisztázása a Kárpát-medence szláv nyelvi viszonyaira vonatkozóan a szláv és a magyar nyelvtörténeti kutatásoknak is fontos feladata.
} 
jellegzetes helynévi tő a szláv nyelvekben, amely többféle képzővel is előfordul helynévként, az *-ovъ képző pedig gyakran járul növénynévi tövekhez; vö. pl. Vrbava, Trnava egy 'füzfa', illetve 'tüske' jelentésủ szóból (ŠMILAUER 1932: 345, 1970: 28, 202, VARSIK 1990: 49-50).

A hosszabb vizek esetében különösen fontos azt is megvizsgálni, hogy a vízfolyás megnevezése mely szakaszára vonatkozóan jöhetett létre. Ennek elemzése eddig éppen amiatt maradhatott háttérben, mivel csak ritkán kecsegtet eredménynyel. Abból a tapasztalatból kiindulva azonban, hogy a vízfolyások ma egységes megnevezése korábban legtöbbször csak szakasznév lehetett (vö. GYÖRFFY 2011: 32-47), szerencsés esetben a névadók területi helyzetére vonatkozó következtetések is levonhatók.

A növénynevek a víznevekben jórészt a vizek melletti növényvilágra utalnak. A gabonatermelés - a táj természeti adottságaiból következően — nagy valószínüséggel a Zsitva Marót és Verebély közti szakaszán (lásd az 1. ábrát) honosodhatott meg legkorábban, mivel feljebb erdők, lejjebb pedig mocsarak szegélyezték a folyót, s ezek egyike sem kedvez a gabonatermelésnek. A szláv víznév keletkezése ezért nagy valószínüséggel a kettő közötti rövid, mintegy $20 \mathrm{~km}$-es folyószakaszra tehető. Mind az Árpád-kori természetföldrajzi környezet, mind pedig az ebből következő településtörténeti viszonyok — amelyet GYÖRFFY GYÖRGY írt le legalaposabban (Gy. 1: 413-489) — alapján a folyó völgyét két nagyobb térségre oszthatjuk: ezek választóvonala nagyjából Verebély környékén húzható meg. A folyóvölgy helynévrendszerét a továbbiakban e területi tagoltságnak megfelelően vizsgálom.

Elemzésem tárgya az a helynévanyag, ami a forrásokban a Zsitva térségére vonatkozóan a korai ómagyar korból, vagyis az 1350 előtti időkből ránk maradt. Ebben a forráskörben 118 település 129 névváltozatáról, illetve szinonim megnevezéséről van tudomásunk. Ez nagy valószínüséggel megközelíti a településneveknek az adott korban ténylegesen létezett elemszámát. A mikronevek közül azonban csupán 49 maradt fenn, ami viszont csak elenyésző töredéke lehet az akkori névállománynak. A Zsitva-völgy alsó és felső térségéböl nagyjából azonos számú településnév maradt ránk — noha az alsó folyószakasz hossza nagyjából kétszerese a felsőének —, a felső térségből ismerjük viszont a mikronevek két harmadát.

Az alábbiakban a két terület nyelvi viszonyait és névrendszerének jellemző vonásait külön-külön mutatom be. 


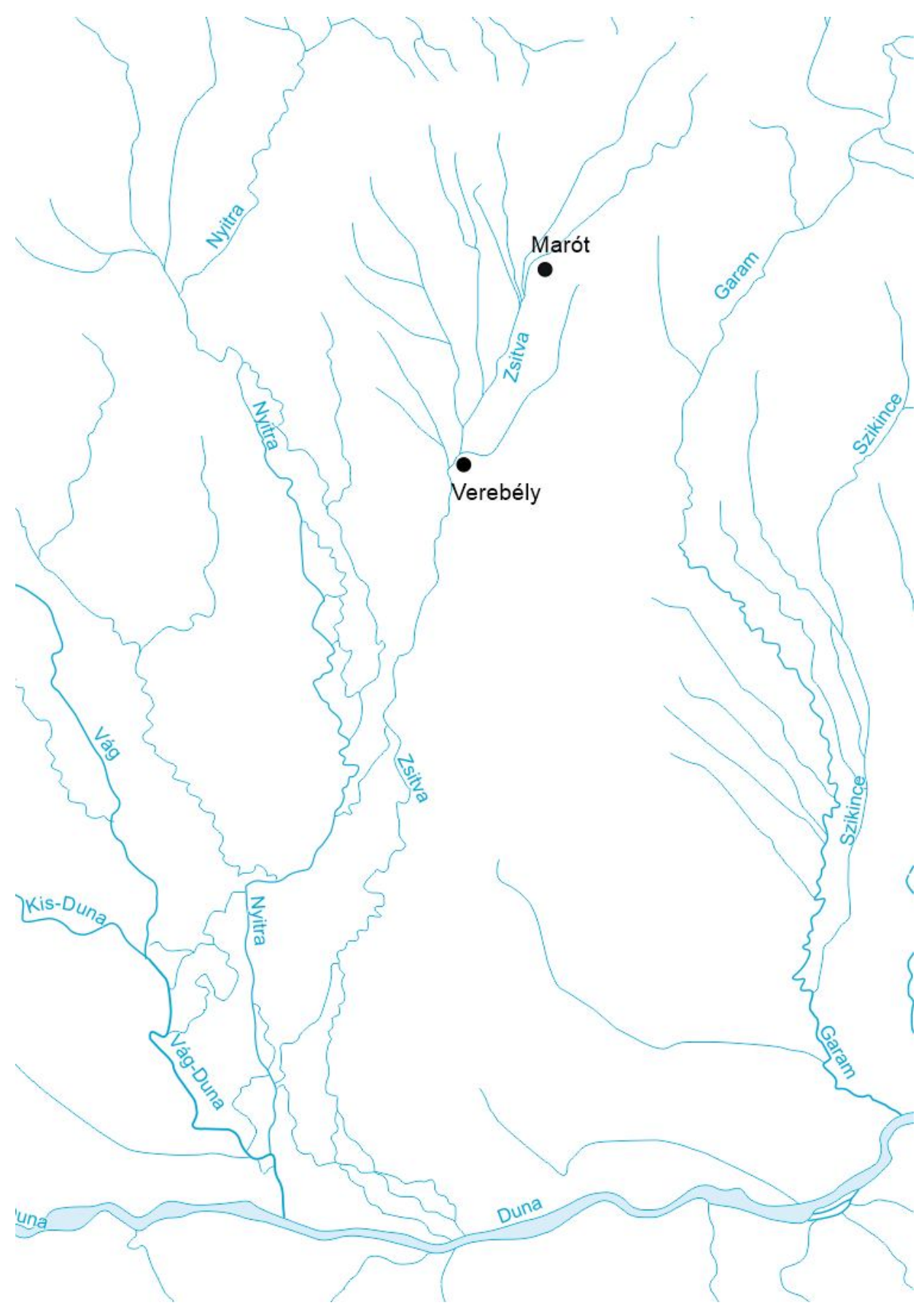

1. ábra. A Zsitva vizrendszere és vízgyüjtö területe 
3. A Zsitva-völgy alsó térségéből a legkorábbi adatokat a 11. század második feléből, az interpolált Garamszentbenedeki alapítólevélnek abból a részéből ismerjük, amelyet névtörténeti szempontból 1075-re vonatkozóan is hitelesnek tarthatunk. Udvard település neve lakóira utaló latinos formában szerepel, emellett az oklevél említi a Tormás patakot és a Zsitva Dunába ömlésének helyét, a Zsitva tövé-t. Ezek mindegyike kétségkívül magyar eredetủ helynév, noha ez utóbbi alapjául a magyarba szláv átvétel révén bekerült folyóvíz neve szolgált.

A Zsitva alsó folyása mellett előforduló 57 településnév 53 településre utal, tehát mindössze 4 megnevezés szerepel alakváltozatként, illetve szinonimaként. A 11. században feltünő egyetlen településnevet a 12. század második felében mindössze 5 további követi, a legtöbb név (42) a 13. századból adatolható elsőként, további 9 pedig csak a 14. század első felében tünik fel. (Az adatok időbeli megoszlásához lásd a 7. ábrát.) Az adatok első előfordulásának ez a viszonylagos késeisége a térség gyenge forráshelyzetével magyarázható, és semmiképpen sem következtethetünk belőle mechanikusan a magyarok betelepülésének idejére. Az 53 település és ezek megnevezései nyilvánvalóan nem azonos időben keletkeztek, e folyamatra azonban a nyelvi adatok alapján közvetlenül nem tudunk rávilágítani. A falupusztulás csekély mértékủ lehetett, mivel csupán két településről (Oboz és Tót) nincs tudomásunk a 14. század közepe utáni időkből, továbbá két névváltozatot (Mercsej és Vérttelek), valamint három osztódással alakult település nevét (Al- és Tófüss, Nagyszencse) nem említik ezt követően a források. Ez a helyzet más térségekkel összevetve (lásd pl. Bihar vármegye idevágó adatait, HoFFMANN-RÁCZ-TÓTH 2018: 364-365) a névrendszer nagyfokú stabilitását mutatja, ami összefüggésben lehet a településrendszer és a lakosság folytonosságával is. Összességében azt állapíthatjuk meg, hogy az alább részletezett településnévrendszer csaknem teljes egésze fennállhatott a 14. század közepén.

A továbbiakban névtípusok szerint csoportosítva mutatom be a Zsitva alsó völgyének településneveit.

Személynévből formáns nélkül alakult az itteni településnevek legnagyobb csoportja, ezek nagy részénél a helynév alapjául szolgáló személynév is adatolható ómagyar kori magyarországi forrásokból. Beleg neve szerepel már a Garamszentbenedeki alapítólevélben is $(1075 /+1124 /+1217$ : Bylegi, DHA. 1: 214, SzŐKE 2015: 158), azonban csak az interpoláció során bővített részben, első hiteles forrásból való említése jóval későbbi (1156: Beleg, Gy. 1: 435). Az alapjául szolgáló személynévhez lásd 1138/1329: Beleg (ÁSz.). Lipszkynél ${ }^{2}$ Beleg Belleg néven település. Szencse neve (1156: Scentusa, Gy. 1: 477) a Szentes szn.

\footnotetext{
${ }^{2}$ Az ómagyar kori névalakok újabb kori megfeleléseit többnyire Lipszky János 1806-ból való térképe alapján közlöm, mivel e térségben mind a 19-20. század fordulóján lezajlott településnévrendezés, mind pedig a későbbiekben a (cseh)szlovák közigazgatás gyakran jelentős mértékben módosította a helyneveket.
} 
(1250/1550: Scentus, ÁSz.) - a képzős formájából alakult, a személynév etimológiai szerkezete azonban kevés idő múltán elhomályosodott benne (1258: Scenche, Gy. 1: 477, a változás részleteihez lásd TóTH V. 2001a: 236). Lipszkynél Szencse település. Ény nevét (1156: Eng, 1275: En, Gy. 1: 439) a Jan személynévvel (+1086: Jan, ÁSz.) szokás kapcsolatba hozni, feltéve egy szó eleji já- > é- változást (FNESz., TÓTH V. 2001a: 191). Lipszkynél Ény Iny település. Vajk település neve (1185/1249: Voyku, 1264/1274: Voyk, Gy. 4: 484) GYÖRFFY szerint Szent István ifjúkori nevét őrizheti (i. h.), erre azonban semmi bizonyíték sincs, a személy- és nemzetségnévre ([1001-1009]: Waic, ÁSz.) több adatot is tartalmaznak a források. Lipszkynél Vajk település. Valkász (1221/1550: Wolcaz, Gy. 1: 483) Lipszkynél Valkász, ma Valkház a neve (FNESz.); vö. 1226: Vulcaz szn. (ÁSz.). Hetény (1223: Heten, Gy. 3: 421) Lipszkynél Hetény település; vö. +1086: Heten szn. (ÁSz.). Barócs neve többféle hangszerkezetet mutató alakban is szerepel (1231: Burulch, 1251/1550: Borouch), a 19. századi térképeken Barócs puszta (Gy. 1: 429); vö. 1219/1550: Boroch szn. (ÁSz.). Ás (1236: Ass, Gy. 3: 404) a mai Udvard település határában feküdt; vö. 1228: As szn. (ÁSz.). Mánya (1237: Mana, Gy. 1: 461) Lipszkynél Mánya település; vö. 1171: Mana szn. (ÁSz.). $A b a(1244 / 1422: A b a$, Gy. 3: 402) Lipszkynél $A b a$ puszta Ógyalla határában; vö. 1222/1550: Aba személy- és nemzetségnév (ÁSz.). Pozba (1245: Pazuba, 1327/1382: Pozba, Gy. 1: 467) Lipszkynél Pozba település; vö. +1086: Poscuba szn. (ÁSz.). Barak (1246: Bork, 1322: Barak, Gy. 1: 428) Lipszkynél puszta (Bars)Baracskán; vö. 1229: Bork szn. (ÁSz.). Gyarak (1247: Gorok, Gy. 4: 395) Lipszkynél Gyarak település; vö. 1138/1329: Guruc szn. (ÁSz.). Lót település nevének (1247 u.: Louth, Gy. 3: 437) alapjául jellegzetes magyar személynévalkotási móddal, névrövidítéssel létrehozott személynév szolgálhatott, ami többféle névböl is létrejöhetett, pl. [1247]: Lothar, 1233: Luthart, 1213/1550: Lothardo (ÁSz.). Vék nevének ([1247 u.]: Weyk, Gy. 3: 463) — korabeli [vejk] hangzásából kiindulva — többféle személynév is szolgálhatott az alapjául, pl. 1228/1491: Weyek (ÁSz.). Lipszkynél Vék puszta Ógyalla határában. A Töhöl ([13. sz. k.]: Tvhl, 1262: Tuhul, Gy. 1: 481) alapjául szolgáló személynév illabiális formában adatolható: 1138/1329: Tehel (ÁSz.). Lipszkynél Töhöl település. Barc (1272/1273: Borch, Gy. 1: 429) Lipszkynél puszta; vö. 1233: Barch szn. (ÁSz.). Hull (1290: Hul, Gy. 1: 449) Lipszkynél Hull település; vö. 1234/1243: Houl szn. (ÁSz.). Bese (1292: Bese, Gy. 1: 435) Lipszkynél Bese település; vö. +1080: Bese szn. (ÁSz.). Tild (1297: Teld, 1322: Tyld, Gy. 1: 480) a 1271: Teel szn. (ÁSz.) - $d$ személy- vagy helynévképzős származéka, Lipszkynél Tild település. Rendve neve (1297/1412: Rendwe, Gy. 1: 468) a 1260/1366: Rendue (ÁSz.) személynévből alakult, a településnévnek -j helynévképzővel létrejött Rendvej (1237: Renduuey, Gy. 1: 468) formája is feltünik egy időben. (Más magyarázati lehetőségeire lásd TóTH V. 2001a: 229-230, a képzőről pedig BÉNYEI 2012: 85- 
94.) Lipszkynél Rendve település. Bagota (+1304: Bagata, Gy. 3: 405-406) Lipszkynél Bagota település; vö. +1086: Boguta szn. (ÁSz.). Bajcs (1312: Boych, Gy. 3: 406) Lipszkynél Bajcs település; vö. 1251/1281: Boych szn. (ÁSz.). Gyalla (1329: Gyalla, Gy. 3: 420) Lipszkynél Ó-Gyálla település; vö. 1221/1550: Gala szn. (ÁSz.). Ohaj neve (1293: Vhay, Gy. 1: 464) az Aha személynévből (1280: Ybrahun filius Ahae, ÁSz.) -j helynévképzővel alakult. (Más magyarázattal: FNESz. Ohaj.) Lipszkynél Ohaj település.

$\mathrm{Az}$ alábbi településnevek nagy valószínüséggel ugyancsak személynévből alakulhattak, de keletkezésük magyarázatát gyengíti az a körülmény, hogy velük egyező alakú személynév nem adatolható a középkori magyarországi forrásokból, így többnyire a környező nyelvek köréből hozhatunk rájuk adatokat. Csiffár nevét (1209: Chefar, Gy. 1: 438) KISS LAJOS esetleg német eredetủ személynévből származtatja (FNESz.). Lipszkynél Csiffár település. Lüle neve (1226: Lyvla, Gy. 1: 459) talán szláv eredetü személynévre megy vissza (FNESz.), Lipszkynél Lüle település. Vért neve (1256: Werth, Gy. 3: 463) esetleg német eredetü személynévvel hozható kapcsolatba (FNESz.), Lipszkynél Virth puszta Dunaradvány határában. Mellek (1332: Merlek, Gy. 1: 462) nevének magyarázatához egykori [merlek] ejtése alapján KISS LAJOS szláv és német személynévi párhuzamokat említ (FNESz.). Liszkynél Mellék település.

A társadalmi csoportot jelölő szavakból alakult településneveknek több szemantikai csoportja is megtalálható az itteni helynévanyagban. Három név törzsnévből jött létre: Gyarmat (1232: Gurmot, 1275: Gormoth, Gy. 1: 445), Lipszkynél ugyanezen a néven település; Keszö (1256: Queztev [o: Quezcev], 1258: Kezu, Gy. 3: 425), Lipszkynél Kurta-Keszi település; Kürt (1260: Kyurth, Gy. 3: 435), a 19. sz. közepén kataszteri térképen Kürtelek (Gy. 3: 436). Népnévből alakult Besenyö (1209: Bescene, Gy. 1: 435) és Tót (1299: toud, 1328: Thooth, Gy. 1: 481) település neve. Az előbbi Lipszkynél Besenyő, az utóbbi később nem szerepel a forrásokban. (Ezekről lásd még alább is.) A szölős 'szőlőmüvelő' foglalkozásnévből származik Szölős neve (1258: Sceuleus, Gy. 3: 457), amely ma helynév Hetény határában (i. h.). A szó személynévként is használatos volt (vö. TÓTH V. 2001a: 240). Talán ide sorolható Család település neve (1210: Solad, 1324//1748: Chalad, Gy. 1: 437) is a család régi 'szolga' jelentése alapján (TESz.). KISS LAJOS ennek alapján fogoly szolgák településének tartja (FNESz.). TÓTH VALÉRIA emellett felveti a Csala személynév (1211: Chala) - $d$ személynévképzős alakjából való származtatás lehetőségét is (2001a: 186).

A természeti környezetre többféleképpen utalhat a településnevek szemantikai tartalma. Ilyenek a növénynévből alakult helynevek. Füss neve szerepel már a Garamszentbenedeki alapítólevélben is, de annak az interpolált részében található (DHA. 1: 214, SzÖKE 2015: 168), első hiteles oklevélbeli említése (1156: Fius, Gy. 1: 440) az ottanival azonos alakú. A név a fü főnév -s képzős származéka, 
amely — szokatlan módon — nem a szó $v$-s tövéből alakult (ennek részleteihez lásd TóTH V. 2001a: 193). Lipszkynél Füs Füss település. Harsány neve (1239/1465: Harsan, Gy. 3: 421) a hárs fanév -ny helynévképzős származéka (FNESz., az -ny képzőre lásd BÉNYEI 2012: 103-107), ma Harsányi-dülő Komáromszentpéter határában (Gy. 3: 421). Konkoly település neve ([1247 u.]: Concol, Gy. 3: 433) a konkoly 'egyfajta gyomnövény' főnévből metonímiával alakult. 1851-ben puszta Ógyalla határában (i. h.).

A fenti, növénynévi lexémát tartalmazó településnevek némelyikénél sem zárható ki, hogy esetleg egy azonos alakú mikronévből jöttek létre; az alábbi településnevek viszont biztosan ilyen névböl alakultak metonimikus úton. Setétkút település (1251/1271: Sytetkuth, Gy. 1: 473) sötét vizü forrás mellett létesülhetett, Lipszkynél azonos néven település. Zsitvatö falu a Zsitva Dunába ömlésének helyénél fekszik, korábban vízrajzi névként, Zsitva töve-ként a Garamszentbenedeki alapítólevélnek a 11. századhoz köthető része is említi a helyet $-n$ helyragos formában (1075/+1124/+1217: in Sitouatuin, DHA. 1: 215, SzÖKE 2015: 208). Településnévként azonban csak majd kétszáz évvel később tünik fel (1271/1295/1378: Symatw [o: Sytuatw], Gy. 3: 465). Lipszkynél Zsitvatö puszta Dunaradvány határában. Petkfüze ([13. sz. vége]: Peckfyzu, 1331: Peethkfyuze, Gy. 1: 467) elsődlegesen egy füzfával benőtt terület lehetett, amelynek előtagjában a 1127-1131: Petcu szn. (ÁSz.) szerepel, az utótagként szereplő fanév pedig gyűjtőnévi értelmü. Később nem említik.

A település épített környezetére utalnak azok a nevek, amelyek épületeket jelölő főnevekből alakultak. Udvard település neve a lakóit megjelölő latinos formában szerepel a Garamszentbenedeki alapítólevél 11. századhoz köthető részében: 1075/+1124/+1217: villam Hudwordiensium (DHA. 1: 214, SzÖKE 2015: 203-204), később magyarul említik (1209: Oudouort, 1228/1229: Wdword, Gy. 3: 461). A név a 'nemesi kúria' jelentésű udvar szóból (TESz.) - $d$ helynévképzövel jött létre, s arra utal, hogy itt királyi udvarház létesült (Gy. i. h.). Lipszkynél Udvard település. Baromlak falu neve (1325/16. sz.: nob. de Korumlaky [o: Borumlaky], Gy. 3: 407) a jószág szállásául szolgáló építmény nevéből alakulhatott, ilyen közszói használatára azonban nem ismerek ómagyar kori adatot, településnévként viszont többször is előfordul (KMHsz. 1.). Templomának patrocíniuma szerepel Szentmárton nevében ([1272-1290]: Zenthmarton, Gy. 3: 455). Korábban a Garamszentbenedeki alapítólevél ezen a helyen, Udvard mellett már említ ilyen néven kápolnát. Pestynél 1864-ben a Sz. Márton halma helynév emlékeztet az egykori településre (i. h.).

Fedémes nevét (1239/1465: Fedemus, Gy. 3: 416) egy *fedém 'méhkas, kaptár' szóból származtatja a szakirodalom (pl. FNESz.), ám — ahogyan erre a Tihanyi alapítólevél fidemsi szórványa kapcsán rámutattam (HOFFMANN 2010: 157-160) — erre vonatkozó bizonyítékkal nem rendelkezünk (ilyen közszóra 
ugyanis nincs adatunk), ezért inkább a nagy valószínüséggel magyar, de bizonytalan szemantikai hátterü településnevek csoportjába sorolhatjuk. Ugyanígy minősíthetjük Örs település nevét ([1247 u.]: Vrs, Gy. 3: 447) is, amelynek etimológiai problémáit — új megoldással is bővítve a korábbi felvetéseket — legutóbb KOVÁCS HELGA tekintette át (2014). A 19. század végén puszta Izsa határában (Gy. i. h.).

Peced nevének (1305/1358: Peched) még az alakjában sem lehetünk biztosak, mert a $c$ helyén $t$-vel is említik (1250: Peted, Gy. 3: 449), így a nevet ismeretlen eredetünek tarthatjuk, annál is inkább, hogy később nem szerepel a forrásokban. Nem ismerjük $O b o z$ település nevének (1264: Oboz, Gy. 3: 445) eredetét sem. FEHÉRTÓI KATALIN a településnevet - egyetlen ilyen adatként - felveszi Árpád-kori személynévszótárába (ÁSz.), jelezve a személynévként való azonosítás lehetőségét. Később nem említik.

Elsődleges keletkezésű kétrészes településnév mindössze kettő szerepel a névállományban, mindkettő időleges szinonimaként fordul elö egy-egy fentebb már tárgyalt településnév mellett. Beleg szinonimájaként egyetlen említéssel szerepel Batafölde (1331: Bathafeulde, Gy. 1: 435), amelynek előtagja a korban gyakori személynév (1138/1329: Bata, ÁSz.). Vért névváltozataként ugyancsak egy alkalommal említik a -telek helynévformánssal alkotott Vérttelek névformát (1260: Vertteluk, Gy. 3: 463). Kérdéses, hogy ezek településnévnek tekinthetök-e, vagy inkább Beleg, illetve Vért valamely részét jelölték csupán.

Másodlagos névként, jelzővel való kiegészüléssel jött létre Szencse település egyszeri Nagyszencse említése (1299: Nog Zenche, Gy. 1: 477). Füss település osztódásával alakult $A l$ (só)füss, ezt latin részfordítással jegyezték le (1313/1339: inferiorem Fyus), illetve Tófüss (1313/1339: Toufyus, Gy. 1: 440), amelynek előtagja bizonyára összefügg a falu vízparti fekvésével. Mindkét névformát egyszeri említésből ismerjük.

Amint a fentiekböl kitünik, a Zsitva alsó völgyében csakis magyar eredetü településneveket találunk. (Mindez azt is jelzi, hogy a két ismeretlen eredetủnek minősített név megfejtését is nagy valószínüséggel a magyarban kereshetjük.) Egyedül a Mercse (1329: Merche) és névváltozata, a Mercsej (1279: Merchey, Gy. 3: 439) — amelynek újabb kori előfordulását nem ismerjük — esetében vetödött fel a szláv származtatás lehetősége. KISS LAJOS Sajómercse nevét „valószínüleg szláv eredetü"'-nek mondja, megemlítve a szerb-horvát mräčāj 'lappantyú, bagolyfecske' madárnevet (FNESz.). A borsodi településnévnek éppúgy kétféle — -j-re végződő és anélküli — változata szerepel a forrásokban, mint ahogyan az itt vizsgált Zsitva-völgyi település megnevezésének is. Az efféle kettősség jellemző a -j/-aj/-ej képzős nevek történeti említéseire (vö. TóTH V. 2008: 102, 124 125, BÉNYEI 2012: 85-94), a név alapjául pedig ennek megfelelően a Mercs személynév (1271: Merch, ÁSz.) -e személynévképzős változata szolgálhatott (a névmagyarázathoz részletesebben lásd Póczos 2001: 52-53). A párhuzamos 
névváltozatok metonimikus úton, illetve helynévképzéssel alakultak. A szláv származtatást mind a fenti etimológiai magyarázat, mind pedig a magyar nyelvü névkörnyezet ismeretében elvethetjük.

Magyar eredetüek az itteni mikronevek is, ezek azonban kis számúak, és a településnevekhez képest is kései adatolásúak: a 17 névből a már említett Zsitva töve és a Tormás víznév (1075/+1124/+1217: aquas [...] Tormas et Sitoua, DHA. 1: 214, SzŐKE 2015: 202-203) a 11. századból való, további 7 név a 13. századból, a többi pedig a 14. századból maradt ránk (adataikat részletesen lásd KMHsz. 1., HA. 1: 59-64, HA. 3: 59-70). Ezek jórészt kétrészes víznevek: Lüle pataka (1299/1324: Luepataka [o: Lulepataka]), Vemerd kútja (1299/1324: Wemerdkuta), Nagy-ér (1329: Nogyer), Szék-ér és Szék-fö (1329: Scekeer, Sceefew [o: Scecfew]), Hús? Hüs?-tó (1329: Hustow), közülük négyet éppen Mercse(j) határában említenek. Az egyrészes, földrajzi köznévvel azonos alakú említések tulajdonnevek és közszók egyaránt lehetnek: két Haraszt (1227: horost, 1265: Harast, Gy. 1: 440, 425), Eresztvény (1231: Eresteun, Gy. 1: 440), Bérc (1260: berc, Gy. 3: 464), Ravaszlyuk (1260: Rowozlyuk, Gy. 3: 464), Telek (1260: teluk, Gy. 3: 464), Aszó (1313/1339: Ozou, Gy. 1: 441), Patak (1327: Patak, Gy. 1: 459), Halom (1345: Holm, Gy. 3: 422). (Ezek nyelvi státuszának értékeléséhez lásd HOFFMANN 2004: 52-57.)

Betelepülő — adott esetben más nyelvü — népességre utal a fentiekben már említett Besenyő és Tót neve (e településnév-típushoz és a bennük található etnonimákhoz lásd RÁCZ A. 2011: 17-27, 169-196 és 2016: 35-37, 92-95), de a betelepülők nyelvi helyzetéről, illetve ennek feltehető változásáról nincsenek ismereteink. Azt azonban tudjuk, hogy a 13. század elején feltünő Besenyő lakóit a szomszédos Udvardon már a Garamszentbenedeki alapítólevélben is említik (lásd fentebb, illetve Gy. 1: 435-436, Gy. 3: 461, KRISTÓ 2003: 70).

4. A Zsitva felső szakaszán és itteni mellékvizeinek a völgyében 65 települést jelölö 72 név fordul elő a korai ómagyar korban, amelyből 4 alakváltozat, 3 pedig szinonim (esetleg más nyelvbeli) névváltozat. E térségből két nevet említ a Garamszentbenedeki alapítólevél: Taszár és Zsikva települését, mindkettő az oklevél 11. századra tehető rétegéhez köthető (DHA. 1: 214, SzÖKE 2015: 200, 207). A 12. századból 16 név maradt ránk, a következő századból 43, a 14. század első feléből pedig további 11. Ez összességében azt mutatja, hogy e térség forrásadottságai valamivel kedvezőbbek az időbeliség tekintetében, mint az alsó folyószakaszé. (Az adatok időbeli megoszlásához lásd a 7. ábrát.) Ezt jelzi az itteni 35 mikrotoponima is. Csupán öt településröl (Kisfalud, Kolbász, Patkánytelek, Selk, Ulog) nincs tudomásunk a 14. század utáni időkből, és három alakváltozatnak (Hecseny, Kálozd, Szelepcse) nincs későbbi nyoma. Mindez — ahogyan az alsó folyószakasznál is - a névrendszer és ezzel együtt vélhetően a településrendszer nagyfokú állandóságára utal. 
A Zsitva felső szakaszán található helyneveket a jobb áttekinthetőség végett térképeken is ábrázolom (lásd a 3. és a 4. ábrát).

Az itteni településnevek az alábbi névtípusokba tartoznak.

A középkori magyarországi oklevelekből is adatolható személynevekből jöttek létre metonimikus úton az alábbi településnevek. Kolon települést nevének korai előfordulása (+1111/1414: Colyn, később 1251: Colun, Gy. 4: 409) alapján a 1278: Kolyn (ÁSz.) személynévvel kapcsolhatjuk össze, a későbbi-mai alak ebből magyarázható. A Kárpát-medencében fekvő többi Kolon település nevének elemzése azonban további lehetőségeket is felvet (vö. HoFFMANN 2010: 170175). Lipszkynél Kolon település. Néver (1156: Neuir, Gy. 1: 464) Lipszkynél azonos nevü település; vö. 1219/1550: Neuer szn. (ÁSz.). Zsigárt neve többféle hangalakban is szerepel (1156: Asgar, 1232: Ysgar, 1280/1291: Sygarth, Gy. 4: 493), az ómagyar kor után azonban nem említik. A tőle nem túl messze fekvő Zsigárd adatai alapján is a német eredetü 1237: Sygart (ÁSz.) személynévből származtathatjuk (FNESz.). Zsigárt korai adatai ebben az esetben hangátvetéssel alakult formát jelezhetnek. Künd(i) település (1156: Cundi, Gy. 1: 450) nevének újabb kori említéseit nem ismerjük, a Künd személynév véghangzós formájából származik (1138/1329: Cundi, ÁSz.), de nem zárható ki az sem, hogy a név végén - $i$ személy- vagy helynévképző szerepel. GYÖRFFY a kend néprész településének mondja (i. h.). Személynévből $-d$ helynévképzővel jött létre Bélád neve (1156: Belad, Gy. 1: 433-434); vö. +1086: Bela szn. (ÁSz.). Lipszkynél Belád. Vezekény (+1209/17. sz.: Wezeken, Gy. 1: 485) Lipszkynél azonos nevü település; vö. 1264: Wezeken személy- és nemzetségnév (ÁSz.). Jóka (1229: Jovka, Gy. 1: 449) egy 20. század elejéről való térképen Jóka hegy (i. h.); vö. 1265/18. sz.: Joka szn. (ÁSz.). Geszte nevét (1232: Guesta, 1274: Guezte, Gy. 4: 391) KISS LAJOS ugyanúgy a geszt 'gyümölcs fás héja' szóból magyarázza, mint a Geszt nevekét, de „ahhoz képest - $a \sim-e$ képzővel bővült”-nek mondja (FNESz. Nyitrageszte). Ilyen helynévképzőt azonban nem ismerünk. Valószínübb magyarázatként jöhet szóba a Geszteréd személynév (1262: Guestred, ÁSz.) feltehető rövidült alakjából való eredeztetése. Lipszkynél Geszthe település. Hind (1234/1364: Hymd, 1264: Hind, Gy. 4: 397) korai alakjai jelzik, hogy a 1138/1329: Himudi személynévből (ÁSz.) eredeztethető (vö. FNESz. Nagyhind). Lipszkynél Hind. Henyőc település (1246: Heneuch) a 19. század végén Hunyócz puszta (Gy. 1: 448); vö. 1219/1550: Henuc szn. (ÁSz.). Kernye nevének (1248/1291: Kerne, Gy. 4: 406) újkori említéseit nem ismerjük; vö. [1280]: Kerne szn. (ÁSz.). Aha neve (1265: Aha, Gy. 1: 425) az Ohaj településnél említett Aha személynévből való. Verebély (1265: Verebeb [э: Verebel], 1274: Werebel, Gy. 1: 485) Lipszkynél azonos nevü település; vö. 1202-1203/1500 k.: Verbel szn. (ÁSz.). Mahola neve (1275: Mohala, Gy. 1: 460) a 1131: Mahal szn. (ÁSz.) -a személynévképzős változatából alakulhatott, később Maholány néven szerepel (FNESz., TóTH V. 2001a: 216). Bodok (+1287: 
Bodok, Gy. 4: 357) Lipszkynél Kis-Bodok; vö. 1261/1309: Bodouk szn. (ÁSz.). Selk neve (1292: Sylk, 1294: Selk, Gy. 1: 473), amely később nem szerepel a forrásokban, KISS LAJOS szerint német személynevekkel hozható kapcsolatba (FNESz. Nagyselyk), de lásd még esetleg 1318: Selke szn. (SLíz 2011: 442). Kolbász települést (1292: Colbaz, Gy. 1: 452) kunok lakták, ez egybevág azzal, hogy az azonos nevü, Kunhegyes melletti település nevét KISS LAJOS a kun eredetü 1459: Kolbaz személynévből származtatja (FNESz.). Később nem említik. Munkád település neve (1319: Monkad, Gy. 1: 463) 19. századi kataszteri térképen Munkács helynévként szerepel Verebély határában; vö. +1214/1334: Monchad szn. (ÁSz.). Szovaj település neve (1326: Zowey, 1327: Soway, Gy. 1: 478) egy szláv eredetủ Szava személynévből alakulhatott (vö. FNESz. Szava) -j helynévképzővel. (A személynévhez lásd esetleg 1211: Zouafeereh, ÁSz., KovÁcS É. 2015: 111, illetve 1358: Zoua szn., SLíz 2011: 284.) Ebből jött létre szabályos hangtani változással az egyetlen adattal szereplö Szoé névforma (1324: Zoe, Gy. 1: 478). Analógiaként többek között az Abaúj vármegyei Novaj Noé példáját említhetjük (ehhez lásd TóTH V. 2001a: 109-110, 239-240). A településnek újabb kori említését nem ismerjük.

Hecse nevét (1268: Heche, korábban a rajta átfolyó víz neveként: 1234/1364: Hecha, Gy. 1: 447) KISS LAJOS egy szlovák Choča helynév átvételének tartja, amely hangrendi átcsapással nyerte el magyar nyelvi alakját (FNESz., lényegében ugyanígy, de részletezően és árnyaltabban TóTH V. 2001a: 201). Kézenfekvőbb azonban összekapcsolni a 1269/1397: Hecha, +1214/1334: Hetze (ÁSz.) típusú személynevekkel, amelyekből közvetlenül alakulhatott. Hecseny névváltozata (1275: Hetchen, Gy. 1: 447) a 13. század végén jelentkezik csupán, ez a településnév -ny helynévképzővel történő másodlagos bővülésével alakulhatott, leginkább a környező, hasonló végződésủ településnevek hatására (ugyanígy TÓTH V. i. h.; az -ny helynévképzőhöz lásd BÉNYEI 2012: 103-107). Lipszkynél Hecse település.

Az alábbi településneveket olyan személynevekkel hozhatjuk kapcsolatba, amelyek ismereteim szerint nem szerepelnek középkori magyarországi forrásokban, így magyarázatuk az előbbiekénél némileg bizonytalanabb lábakon áll. Zsére nevét (1113: Sire, Gy. 4: 493), amely Lipszkynél ugyanilyen formában szerepel, KISS LAJOS szláv személynévből származtatja (FNESz.). Ugyanő Hizér neve (+1209/17. sz.: Hyzer, Gy. 1: 448) mögött német személynevet sejt (FNESz.). Lipszky Hizér Hezér néven említi. Nyevegy nevét (1229: Nywg, 1234/1364: Nyveg, Gy. 1:464) bizonytalan magyar személynév-előfordulás mellett szláv eredetű személynévvel kapcsolja össze a szakirodalom (FNESz. Néved, Nyüved, TóTH V. 2001a: 222). Lipszkynél Néved település. A településnevek alapjául szolgáló személynevek idegen eredete természetesen nem érinti a településnevek magyar nyelvi származtatását, mivel mindegyik — az indoeurópai nyelvekre nem 
jellemző - metonimikus úton, illetve jellegzetes magyar helynévképzővel keletkezett.

A társadalmi csoportnevekből alkotott településneveknek két szemantikai típusa jelenik meg a Zsitva felső völgyében. Foglalkozásnévből három település megnevezése alakult: - $i$ képzővel jött létre Kovácsi-é (1274/1329: Koachy, Gy. 4: 413), amelyet a 14. század után nem említenek, formáns nélkül pedig Dusnok-é (1319: Dusnuk, Gy. 1: 438), amely a dusnok 'egyházszolga, torló' köznévből alakult (vö. FNESz.), de TÓTH VALÉRIA a személynévi áttétel lehetőségére is felhívja a figyelmet (2001a: 190). Ez utóbbi a 19. századi kataszteri térképen Verebély határában puszta (Gy. i. h.). Talán ebbe a szemantikai csoportba sorolható az öt Nyitra vármegyei Család település egyike is (1232: Chalad, Gy. 4: 364), e név magyarázatát a Zsitva alsó szakaszának neveit tárgyalva már megadtam. Lipszkynél Család település.

Népnév az alapja két település nevének. Mivel e tanulmány elsőrendủ célja a nyelvi kapcsolatok vizsgálata, ezek eredetét és történetét a többi településnévnél részletezőbben tárgyalom. Marót neve morva betelepülőkre utal, első említésében (1113//1410: v. Morowa) a ma is használatos morva népnevet tartalmazza eredeti alakjában, később azonban már az ennek szinonimájaként használt marót népnévvel jelölték (1284: Marouth, Gy. 1: 461). Adatok sora igazolja, hogy a régi magyar nyelvben mindkét etnonima használatos volt, és több esetben is egymással váltakozva fordulnak elő helynévként (RÁCZ A. 2016: 62-64, a helynévi elöfordulásaira RÁCZ A. 2011: 79-83). Általános felfogás szerint a településnév és a többi hasonló is - egy régi szláv *Moravbcr helynév átvétele (vö. pl. az éppen itt tárgyalt névről: FNESz. Aranyosmarót). A név hangalakjáról arra is következtetnek, hogy „A magyar - $t$ a szláv - $c$ helyén igen régi átvételre mutat, amikor a magyarban még nem volt c" (KNIEZSA 1947-1949: 24). Ennek alapján KISS LAJOS a településnév átvételének idejét a 10. századra vagy Szent István korára teszi (1999: 234). A betelepülő népeket azonban a környező magyarság a saját nyelvén, magyarul nevezte el (ehhez általános érvénnyel lásd RÁCZ A. 2011, 2016). A marót népnév valóban a fenti szláv formára vezethető vissza, amelynek átvétele még nem $c$-vel, hanem $t$-vel történt, de a szónak van későbbi adaptációra utaló maróc alakja is, amely ugyancsak szerepel - változatként is - településnevekben (RÁCZ A. 2016: 62-63). A közszó régiségéből azonban nem következtethetünk közvetlenül a belöle alakult településnév régiségére: ennek az első említése (1113) elötti megléte nyelvészeti ismeretek alapján ugyanis nem igazolható. Népességéről annyit tudunk még, hogy IV. Béla király idején keresztény kunok lakják (Gy. 1: 461).

Káloz neve iráni nyelvet beszélő kálizokra utal, akik a magyarországi pénzügyek intézésében játszottak fontos szerepet. Első említésüket Kálmán király zobori okleveléből ismerjük, ami esetleg Nyitra vármegyei illetékességüket jelezheti, és lakhelyük talán azonosítható a csaknem fél évszázaddal később említett 
Káloz településsel (1156: Qualiz, Gy. 4: 402, KRISTÓ 2003: 45). A helynév azonban magyar eredetü, amit a később megjelenő - $d$ képzős Kálozd változata (1298: Kaluzd, Gy. 4: 402) is jelez. (A népnévhez és helynévi szerepéhez lásd RÁCZ A. 2011: 47-48, 2016: 49-52.) A falu lakóinak nyelvi helyzetéről nincsenek ismereteink. Lipszkynél Kalász település, e névalak az etnonimának a nyelvhasználatból való kiesését is jelzi (vö. még FNESz. Budakalász).

Többféle szemantikai jegy alapján utalnak a természeti környezetre egyes településnevek a Zsitva felső völgyében. A hárs fanévből a fentebb már tárgyalt módon alakult Harsány neve (1229: Horsan, Gy. 4: 396), amelynek szláv névmegfelelöjére alább térek ki. Szemantikai tekintetben nem probléma nélkül való Gesztőgy nevének (1209: Gesteuge, Gy. 1: 444) magyarázata, amelyet a szakirodalom a geszt 'gyümölcs fás héja' szóból magyaráz (FNESz. Gesztőd, TóTH V. 2001a: 198). E magyarázat mellett szól azonban az a körülmény, hogy a -gy képző többnyire növénynevekhez járulva alkotott helyneveket (BÉNYEI 2012: 70-74). Az -i helynévképzővel alakult Bori neve (1275: Buri, Gy. 1: 436), amelynek újabb kori említését nem ismerjük. Származtathatjuk egyrészt a +1086: Bor személynévből (ÁSz.), de TÓTH VALÉRIA megalapozottan veti fel azt a lehetőséget is, hogy tövében a régi magyar bór 'erdei fenyő' fönevet keressük (2001a: 184). A térség hegyeit ugyanis a 18-19. századi katonai térképeken - ahogyan ma is — erdők borítják (K1, K2). Hasonló természetföldrajzi, továbbá névkörnyezeti érvek alapján tekinti növénynévből származónak KISS LAJOS a Hont vármegyei Bori település nevét (FNESz.). A gím 'nőstényszarvas' állatnévből -s képzővel jött létre Gímes neve (1113: Gimes, Gy. 4: 391), amely Lipszkynél Gímes Ghimes településként szerepel (vö. FNESz. Ghymes). A sár földrajzi köznévböl -i helynévképzővel alakult Sári neve (1298: Saari, Gy. 1:471), amely már a Garamszentbenedeki alapítólevélben is szerepel, de annak csak az interpolált részében (DHA. 1: 214, SzŐKE 2015: 192-193). A név alapjául emellett személynév is szóba jöhet (То́тн V. 2001a: 231), azonban a település lapos, vízparti fekvése miatt soroltam mégis a természeti környezetre utaló nevek közé. Lipszkynél Sári falu. A Zsikva folyó névformája a magyarban alakult ki (lásd alább), a mellette fekvő település nevévé (1075/+1124/+1217: Sikua, Gy. 1: 489) metonimikus úton vált, a folyónév eredetéből következően bizonyára magyar névadók révén. Mind a folyó, mind a település neve a Garamszentbenedeki alapítólevél 11. századra tehető részében szerepel (DHA. 1:214). Lipszkynél Zsikava település. Ugyanígy alakult Rohozsnica település neve (1283: Rohosnicha, Gy. 1: 469) is a mellette fekvő, azonos nevet viselő patak nevéből. A víznév a szlávból való, elsődlegességét a település nevéhez képest jelentéstani körülmények magyarázzák (lásd alább). A település nevét szlávok és magyarok egyaránt adhatták, a névkörnyezete alapján azonban inkább talán szlávokra gyanakodhatunk. Lipszkynél Rohosnicza település. 
Az épített környezetre utaló településnevek is találhatók a vizsgált területen. $D(o) \operatorname{vor}(d)$ falunak a korabeli névalakját sem könnyü meghatározni, mivel mindössze két forrásban maradt ránk, a zobori oklevélben (1111: Doardi, DHA. 1: 382) és néhány évtizeddel később képző nélküli (1156: Duor, Gy. 4: 376) formában. Rekonstruálásában segítségünkre vannak a szintén Nyitra vármegyében szereplö Dovor említései, amelyek között a fentivel azonos névalak (1246: Duor) — ez [dvor] és [duor] ejtésformát egyaránt takarhat — mellett 1244/XVI.: Duwor és 1327: Dowor formákat találunk (Gy. 4:376). A nevet kétségkívül a szláv dvorz 'kúria, palota' szóra lehet visszavezetni, amely közszóként a magyarba is átkerült (TESz. udvar). A kérdés elsősorban az, hogy a szlávban vagy a magyarban alakult-e belőle az említett helynév. A [dvor]-ként rekonstruálható formák szókezdő mássalhangzó-kapcsolata alapján szláv névadókra, névhasználókra gondolhatnánk inkább, csakhogy a szlávban e névszótő mindig névformánssal együtt szerepel helynévként (pl. szlovák Dvorčany, cseh Dvořiště, ŠMILAUER 1970: 58). A szláv nyelvekre általában sem jellemzők a névformáns nélkül álló nevek, a magyarban viszont az épített környezetre utaló településnevek körében is rendkívül gyakori a metonimikus névalkotás. Az udvar esetében pedig feltehető, hogy egyes térségekben - a magyarban eleinte az eredeti szláv szókezdő mássalhangzó-kapcsolatot tartalmazó formájában használták, mivel a nyelvi adaptáció nem feltétlenül jár együtt a torlódás feloldásával (lásd ehhez KENYHERCZ 2013, különösen 98, 147-148). A hangtani adaptáció pedig nemcsak előtéthanggal történhetett, hanem a bizonyos tekintetben „szabályosabb”, gyakoribb eljárással is: a két mássalhangzó közé bontóhang beiktatásával (NYIRKOS 1993: 39-80), dovor formát eredményezve. Erre a lehetőségre - más összefüggésben — KNIEZSA is utal (1955/1974: I, 539-540), és megemlíti ezt a lehetőséget GYÖRFFY is (Gy. 4: 376). A fenti Dovor helynévalakok tehát a magyarba átkerült közszóból alakulhattak metonímiával, magyar nyelvü névadók révén. A Doardi forma - a $v$ hiánya ebben magánhangzóközi helyzetben történt kiesést jelez — pedig a név - $d(i)$ képzős változata ugyanúgy, ahogyan ezt a folyó alsó völgyében tárgyalt $U d v a r d$ esetében is láttuk. Talán nem véletlen az sem, hogy később e falu közelében Teremes néven (1358: Theremus, Gy. 4: 476) tünik fel egy település: ennek szemantikai háttere — a terem 'nagy helyiség' jelentése alapján (TESz.) — lényegében megegyezik Dovor-éval (vö. FNESz. Terem).

Közvetve ugyancsak az épített környezetre, a település templomára utalnak a patrocíniumokból létrejött településnevek, amelyböl kettő is van térségünkben, mindkettő - e névtípusban gyakori módon - latin nyelven említve: Keresztúr (1332: S. Crucis, Gy. 1: 451) és Szentmárton (1332: S. Martini, Gy. 1: 477), Lipszkynél Keresztúr, valamint Szent-Márton.

Elsődleges alakulású kétrészes településnév mindössze kettő található a névanyagban. Patkánytelek vagy Patkánytelke nevének (1292: Pathkanteluk, 1294: 
Patkanteleke, Gy. 1: 466) előtagja a Patkány személynév (1138/1329: Patkan, ÁSz.), amely a telek(e) településnév-formánssal alkot helynevet. Később nem említik. Kisfalud (1295: Kisfolud, Gy. 4: 409) neve az ómagyar korban gyakori névformát képvisel (KÁZMÉR 1970: 156-158), e település neve sem szerepel később a forrásokban.

Másodlagosan, a Tapolcsány településnév jelzővel történő kiegészítésével hozták létre Kistapolcsány nevét (1293: Topolchen parvum, 1318: Kustapulchan, Gy. 1: 479), elkülönítve a közeli Nagytapolcsány-tól. A faluosztódás révén létrejött Kis- és Nagyhecse (+1209/17. sz.: Parvo Hecze, Magni Hecze, Gy. 1: 447) ugyancsak másodlagos alakulású nevének előtagját latin nyelven írják a források. A kései átiratban tévesen tagolt alakban maradt fenn a jelzős szerkezetü Kisszelepcsény (1264>18. sz.: Kiszelw-Pecheny) névforma (TóTH V. 2001a: 207-208).

A Zsitva felső szakasza és mellékvizei környezetében jelentős számú szláv eredetű településnevet találunk. Ezek többségének korai ómagyar kori adatai a név magyar nyelvbeli adaptációját is jelzik már.

Taszár nevét elsőként a Garamszentbenedeki alapítólevél említi (1075/+1124/ +1217: Tazzar, DHA. 1: 214, SzÖKE 2015: 200). A név ugyan az oklevél 11. századi rétegéhez köthető, a hangalakját a többszörös átírás miatt azonban nem tekinthetjük a mondott korra vonatkozóan kétségkívül hitelesnek. A név egy szláv *Tesari 'ácsok' jelentésü településnévre vezethető vissza, amelynek hangrendi szempontból kiegyenlített Taszár, illetve Teszér formái váltakozva szerepelnek a forrásokban, az eredeti vegyes hangrendű formákkal együtt. ${ }^{3} \mathrm{E}$ helyen csak azt jegyzem meg, hogy a névhasználatnak ez a sajátos sokfélesége — amely a Kárpát-medence más Taszár, Teszér nevei körében nem tapasztalható — bizonyára azt jelzi, hogy szláv és magyar nyelvủ névhasználók egyaránt éltek a településen, illetve a környezetében. Erre enged következtetni a településnév közelebbi, alább tárgyalandó (és a 3. ábrán is bemutatott) kétnyelvü névkörnyezete is. Lipszkynél Taszár település.

Szelepcsény neve ([1165 k.]: Selepchen, Gy. 1: 475) a szláv Slepčani településnév átvétele, amely több szláv nyelvben is megtalálható (FNESz.). Már első említése és minden további előfordulása is magyar névhasználókra utal a szó eleji mássalhangzó-kapcsolat feloldásával és a hangrendi kiegyenlítődéssel alakult palatális formával (То́тн V. 2001a: 235-236). Egyetlen Szelepcse alakú említése (1255: Scylipche) — amely a későbbiek tükrében bizonyára valós nyelvhasználati formát tükröz — a határozóragnak vagy helynévképzőnek felfogott szóvégi -ny elvonásával alakult (vö. TóTH V. i. h.). Lipszkynél Szelepcse település. A hangtani adaptáció az előzőekben jelzett formában zajlott le Kelecsény neve (1209:

\footnotetext{
${ }^{3} \mathrm{Az}$ adatokat és a névmagyarázat további részleteit itt nem boncolgatom, mivel ezt a nevet igen alaposan elemzi e kötetben TóTH VALÉRIA tanulmánya (21-48).
} 
Chelecen, Gy. 1: 450) esetében is, amelynek ugyancsak szláv nyelvekbeli megfelelőit ismerjük, pl. cseh Klečany, de a szláv név alapjául szolgáló tő vitatott (FNESz., TÓTH V. 2001a: 205). Lipszkynél azonos néven település. Nemcsény neve (1258>1382: Nempchen, Gy. 1: 463) a szláv 'német (ember)' jelentésủ szóból helynévképzővel alakult, és szlávok közé betelepült német nyelvủ népességre utal. Němčane típusú nevek több szláv nyelvből is adatolhatók (ŠMILAUER 1970: 128, FNESz.). Már a fenti első előfordulása is hangrendileg kiegyenlített forma, illetve az -mcs- hangkapcsolatba betoldott $p$ hanggal szerepel (erre lásd NYIRKOS 1987: 33-34), ami magyar nyelvü névhasználókra utal (TóTH V. 2001a: 221). Lipszkynél azonos néven település. Valkóc neve (1275: Wolkouch, Gy. 1: 483) a személynévként is használatos szláv *vblkъ 'farkas' fönév helynévképzős származéka (ŠMILAUER 1970: 195, FNESz., TÓTH V. 2001a: 246). A szó végi -óc magyar nyelvi adaptációt jelez (KENYHERCZ 2014). Lipszkynél Valkócz település.

Herestény neve (1287: Herescen, Gy. 1: 448, 4: 396) talán nem független a település fentebb tárgyalt Harsány nevétöl sem, noha a szakirodalom a szláv *chvorstъ itt valószínúleg 'bokor' jelentésű szóból (TESz.), illetve ennek szlovák chrast' megfelelöjéből származtatja, amely a -jane képzővel összekapcsolva szerepel (ŠMILAUER 1970: 81, FNESz. Nagyherestény). A 13. század végéig csak magyar adatai vannak, ezt követően jelennek meg a vélhetően szláv veláris formák (1293: Chraccan vel Herestény, 1319: Haraschan, Gy. 1: 448, 4: 396), majd hangrendi átcsapással a valószínúleg magyar palatális változatok. A magyarban ez utóbbi állandósult: Lipszkynél Heresztény, szlovák néven Hrásstany.

Szelezsény neve (1156: Scelemsam, +1209/17. sz.: Zelesen, Gy. 1: 476) ugyancsak szláv eredetü. A szláv név Szilézia nevéből a fent is említett -jane helynévképzővel jött létre, eredeti alakja *Slęžane formában rekonstruálható (FNESz.), szemantikai tartalmából következően pedig sziléziai betelepülőkre utal. GYÖRFFY GYÖRGY szerint ez igen korai esemény lehetett, amit az első névadat második szótagi -em- hangkapcsolata mutat, amely a szláv nazális magánhangzó magyar megfelelője, s e szerint az átvétel a szláv denazalizációt megelőzően történt. A korai adat írásmódja azonban a név végét érintően is kérdéseket vet fel, TÓTH VALÉRIA például romlott alaknak tartja (2001a: 236). A hanghelyettesítéssel való átvételt az sem valószínüsíti, hogy később nem ilyen formában szerepel. A betelepülés pedig aligha magyar környezetbe történt, mivel a magyarság a betelepülöket többnyire a saját nyelvén használt népnévvel jelölte meg, vagy ritkán névköltöztetéssel adott településnév szolgált az új település nevéül (például (Sümeg)Prága, Karakó, FNESz.). A névadók ez esetben viszont szlávok voltak, mégpedig feltehetően nem a betelepülö, hanem sokkal inkább a helyben élő szláv népesség. Ezt az valószínüsíti, hogy a névalakban nincs nyoma a nazális magánhangzónak, ami pedig a sziléziai lengyelben megmaradt. Ehhez azonban azt is hozzá kell tenni, hogy a denazalizáció más szláv nyelvekbeli folyamatának időbeli határait illetően sincs egyértelmü álláspontja a szláv nyelvtörténeti szakirodalomnak (vö. 
ZoLTÁN 2015: 37-38). Szelezsény adatai viszont már magyar névhasználókra utalnak, amit a szókezdő mássalhangzó-kapcsolat feloldása, valamint a hangrendileg kiegyenlített palatális névforma jelez. Figyelemre méltó magyar hangtörténeti szempontból a név $[z s]$ hanggal való átvétele is, amit a későbbi-mai névforma kétségkívül igazol, ugyanis ezt a hangot a korai ómagyar kori forrásokban többnyire az $s$ és a $z$ betük váltakozva jelölik. Lipszkynél Szelezsény település.

Knyezsic (1075/+1124/+1217: Knesecz $\sim$ Knesech, DHA. 1: 213, SzÖKE 2015: 178) neve a Garamszentbenedeki alapítólevélben tủnik fel, amelybe az interpoláció során került be. Első hiteles, eredetiben fennmaradt oklevélbeli említése jóval későbbi (1209: Chenesis, Gy. 1: 452). Töve az ősszláv *kъnędżb 'herceg' méltóságnév, amelyből az -bćb képzővel alkottak helynevet (ŠMILAUER 1970: 28-32, 106). GYÖRFFY a neve alapján arra gondol, hogy a település fejedelmi birtokközpont lehetett (Gy. 1: 452). KISS LAJOS szerint viszont a köznév személynévi használatban szerepel a településnév töveként, amelynek így 'Knäzék' jelentése volt (FNESz. Zsitvakenéz). Megítélésem szerint a kérdés nyelvészeti érvek alapján nem dönthető el. A szláv denazalizáció folyamata e nevet is érintette, a magyar névalakban nincs nyoma az egykori nazális magánhangzónak. Magyar névhasználókra utal az a körülmény, hogy a szókezdő mássalhangzó-torlódás több ómagyar kori adatban (például a fent idézettben) is inetimologikus bontóhanggal áll, ám végül nem ez a forma vált általános használatúvá a magyarban: Lipszkynél Knyezsicz formában szerepel. A név a magyar [zs] hang története szempontjából is figyelmet érdemel.

Hrussó neve (1293: Horsov, Gy. 1: 448) az összláv *gruša 'körte' -ovъ képzős formája (ŠMILAUER 1970: 28, 73), amely azt követően került át a magyarba, hogy a szlovák nyelvben a szó elején megtörtént a $g>h$ változás. Ez a 12. század folyamán zajlott, és a 12-13. század fordulóján ért véget (KNIEZSA 1938: 373). A 13. század végéröl való első névadat és az összes további is magyar névhasználókra utal a szó eleji mássalhangzó-torlódást feloldó magánhangzóval: a Hurusó-féle alakok mellett Hursó típusúak is előfordulnak (vö. TóTH V. 2001a: 203204). Lipszkynél Hrusó várrom.

Kosztolány neve (1113: Costelan, 1253: Koztulan, Gy. 1: 453) az ősszláv *kostel 'templom' fönévre megy vissza, amely a szlovákban később kostol alakban jelentkezik (ŠMILAUER 1970: 96). Ezt a változást tükrözik a név adatai is, az első forma mögött — vegyes hangrendje miatt — nehéz magyar névhasználókat látni. A szláv helynévben a fönévi tőhöz a -jane helynévképző kapcsolódott (ŠMILAUER 1970: 31). Lipszkynél Kosztolán település. A szláv -bcb képzővel (ŠMILAUER 1970: 32) alakult Velcsic neve (1232: Welchez, 1270/1279: Welchuch, Gy. 1: 484), amelynek tövében KISS LAJOS a Velek személynevet azonosítja (FNESz. Velséc). A 13. század második feléből való adat második szótagbeli labiális ( $\ddot{u}$ ö) magánhangzója magyar névhasználókra utal. Ugyanezzel a képzővel alakult 
Lédec neve (1253: Leduch, Gy. 1: 457), amelynek tövében az összláv *lędo 'irtványföld' földrajzi köznév kereshetö (ŠMILAUER 1970: 111, FNESz.). A második szótag labiális magánhangzója [lédöc] e névben is magyar névhasználókat mutat. A magyar névben itt sincs nyoma az egykori szláv nazális magánhangzónak. Lipszkynél Lédecz település.

A térségben további szláv eredetü településnevek is találhatók, ezek azonban a magyar-szláv nyelvi kapcsolatok vizsgálatához nem adnak közvetlen fogódzókat számunkra.

Nemcsic neve (1156: Nemcyc, Gy. 4: 426) a szláv *němbćb 'német (ember)' tőből alakult az -bcb képzővel (ŠMILAUER 1970: 32, 128), és ugyanúgy, mint a korábban említett Nemcsény, szlávok közé betelepült német nyelvü népességre utal. Az újabb korban nem említik. Személynévi tőből (FNESz. Malonya) a szláv -jane képzővel (ŠMILAUER 1970: 30) keletkezhetett Malonyán neve (+1209/17. sz.: Molonyan, 1246: Molonan, Gy. 1: 461). Lipszkynél későbbi változás eredményeképpen Malonya (vö. TóTH V. 2001a: 217). Ezzel a képzővel jött létre Tapolcsány neve is, amelyet — elkülönítve a közeli, Nyitrától északra fekvő (Nagy)Tapolcsánytól — többnyire Kistapolcsány-nak említenek (1293: Topolchen parvum, 1318: Kustapulchan, 1358>1364: Tapolchan, Gy. 1: 479). A név tövében a szláv *topolb 'nyárfa' növénynév rejlik (ŠMILAUER 1970: 182, FNESz. Nagytapolcsány). Lipszkynél (Kis)Tapolcsány. Tajna nevét (+1075/+1124/+1217: Taina, DHA. 1: 214, SzÖKE 2015: 199) a Garamszentbenedeki alapítólevél interpolált része tartalmazza, hiteles, eredeti oklevélben csak jóval később fordul elő (1209: Tayna, Gy. 1: 479). ŠMILAUER az ősszláv *tajbns 'otthoni, hazai' tő származékának tartja (1970: 180). KISS LAJOS — kevésbé meggyőzően — talán az összláv *tajati 'olvad' vagy *tajiti 'eltitkol' ige származékának mondja (FNESz. Tajnasári). Lipszkynél Káptalan- vagy (Nemes)Tajna.

Babindal neve (1271: Babyndal, Gy. 4: 346) bizonyára egy *Babbnъ dols mikrotoponimára vezethető vissza, arra utalóan, hogy a falu egy kis patak völgyében fekszik. Az ősszláv *dolb 'völgy' szlovák megfelelője (ŠMILAUER 1970: 56) egy Baba előtaghoz kapcsolódott. Ez az előtag bizonyára azonos a zobori oklevélben a Babindallal szomszédos Dovorral összefüggésben említett Baba névvel (1111: Baba pars, Gy. 4: 376), amelyet GYÖRFFY nem tekint helynévnek, hanem 'anyai, ősi?' értelmünek gondol, igaz, kérdőjellel. KNIEZSA viszont a helynevek között tárgyalja, és a szláv baba 'asszony' szóból származtatja (1947-1949: 7). A Babindal előtagja ennek vagy a belőle alakult személynévnek, de még inkább egy ezekből létrejött helynévnek a valamihez tartozást kifejező - bnъ képzős (ŠMILAUER 1970: 28-31) formája. Lipszkynél Babindal település.

Goloh nevét (1209: Golluch, Gy. 1: 445) TÓTH VALÉRIA a szlávból magyarázza (2001a: 198), a részletek tisztázatlansága miatt azonban inkább a bizonytalan eredetű nevek közé célszerü besorolni. Többféle magyarázat vetődött fel Ebedec neve (1322: Ebedicz, Gy. 1: 438) kapcsán is (FNESz., TóTH V. 2001a: 190), 
azonban egyik sem igazán meggyőző. Ezek pontosításánál figyelembe kell venni a név egy-egy adattal jelentkező Ebic (1324: Ebyz) és Abic(k) (1324: Abyck) változatát is, mivel ezek a későbbiekben is élő formák: Lipszkynél magyarul Ebedecz, szlovákul Obice, németül Obitz. Az összefüggések megnyugtató tisztázásáig e névformákat helyesebb bizonytalan eredetűnek tartanunk.

Buzsic nevének ([1205-35]: Busic, 1294: Busuch, Gy. 1: 437) rekonstruálása ugyancsak bizonytalan, eredetét ismeretlennek tekintem, noha FEHÉRTÓI személynévi adatként veszi fel az előfordulásait (ÁSz.). Ismeretlen eredetű Oszna (1327: Ozna, Gy. 1: 426) és Ulog (1323: Vlog, Gy. 1: 483) települések neve is, amelyeknek újabb kori előfordulásait nem ismerjük.

A Zsitva felső szakaszának területéről valamivel több mikrotoponimát ismerünk, mint amennyit az alsó völgyéből, ám az időbeli eloszlása ezeknek is igen egyenetlen. A 11. századból, a Garamszentbendeki alapítólevélből a Zsitva neve mellett egyedül a Zsikva folyónév maradt fenn, a 12. századból is csupán további 2 adattal rendelkezünk, a 13. századból való az adatok zöme (25), és 14. századi újabb 3 adat.

A természeti nevek között a Zsitváé mellett legfeljebb még a Tribecs hegység neve (1113: Trebisc, az e részben következő nevek további adatait lásd KMHsz. 1., HA. 1: 59-64, HA. 4: 55-69) lehetett olyan, amelyet nem csupán az ezen a vidéken élők, hanem a valamelyest távolabb lakók is ismerhettek. A hegynév az ősszláv *terbi(ti) *trebi(ti) 'irt' ige -išče képzős, 'irtás' értelmü fönévi származékából alakult (ŠMILAUER 1970: 28-31, 180). Később a magyar és a szlovák alakban is a két szótag magánhangzója hangátvetés révén helyet cserélt. A magyar névformában megmaradt a szókezdő mássalhangzó-kapcsolat.

A többi név ismertsége aligha terjedt túl a Zsitva-völgy térségén, sőt jó néhány közülük mindössze csak néhány településen lehetett használatos. E területen belül viszonylag szélesebb körben legfeljebb a több települést átszelő patakoknak, a Zsitva mellékvizeinek a neveit ismerhették. Ezek között többségben vannak azok, amelyeknek a neve szláv eredetü. A Dervence (1113: Dreuenizza, 1229: Deruenche) Kosztolány és Lédec felől érkezik a Zsitvába. A név az ősszláv *dervo *drъvo 'élö fa, erdő' tőből - amelynek szlovák megfelelője a drevo — alakult a -nica helynévképzővel (ŠMILAUER 1970: 29-31, 53). A legkorábbi adat a név eredeti, szláv hangzását mutatja (de akár már ilyen formában is hangozhatott magyar ajkakon is), a bö évszázaddal későbbi említés azonban többrendbeli hangváltozáson átesett, adaptálódott magyar névformát mutat (vö. TÓTH V. 2001a: 189).

Taszár határában érte el a Zsitvát a Sztranya patak (+1209/17. sz.: Stranya). A név alapja az ősszláv *storna, későbbi szlovák strana lehet, amely itt leginkább 'hegyoldal' jelentésben szerepelhet (ŠMILAUER 1970: 170). A Topolnyica neve (1324: Thopolnica) ugyanabból a szláv topolb 'nyárfa' tőből származik, mint a 
mellette fekvő Tapolcsány település megnevezése, ez esetben viszont a -nica képző járult a tőhöz (ŠMILAUER 1970: 29-31). A Rohozsnica (1284: Rasnicha, 1295: Rohoznicha) a vele azonos nevü település és Nemcsény mellett elhaladva balról ömlik a Zsitvába. A név tövében az ősszláv *rogozъ 'nád' rejlik, ehhez járult hozzá a -nica képző (ŠMILAUER 1970: 28-31, 153). A víznév elsődlegességét a település nevéhez képest a név — e névfajta esetében igen gyakori — növénynévi eredete valószínúsíti. Az adatok a szlovákban lezajlott $g>h$ változást jelzik, a név magyarba való átkerülésének kérdésére alább térek ki. A három szótagos formák a magyarban a magánhangzóközi - $h$ - kiesését követő szótagösszevonást mutatják. E patak jobb oldali mellékvize a Szince (1295: Scinche), amelynek tövében talán az ősszláv sinъ 'kék' melléknevet kereshetjük, amelyhez az -ice képző járulhatott (ŠMILAUER 1970: 29-32, 161), de szóba jöhetnek más szláv tőből való magyarázatok is (vö. TóTH V. 2001a: 238).

A Zsitva egyik forráságának, a Zsikvá-nak a neve (1075/+1124/+1217: Sikua) magyar névhasználók nyelvében alakult ki, ugyanis a magyarban nem ritka a $t>$ $k$ változás, különösen mássalhangzó-kapcsolatok első elemeként (KISS L. 1999: 83). Ugyanez a vízfolyás - vagy esetleg csak az alsó szakasza — viselhette a Kis-Zsitva (1318: Kywssytua) nevet is. Hecse településen folyik át a Hecse-patak (1275: Hetche potok), ennek földrajzi köznév nélküli említését (1234/1364: fluvius Hecha) is ismerjük, ez azonban inkább 'Hecse (település) patakja' értelmü lehet. Harsány település vize, a Körös (1274: Kevrus) a magyar köris fanévböl való, s ahogyan a település elsődleges neve is, magyar nyelvü névadókra utal. Gímes település patakját - latinra fordított elötaggal — Kis-Gímes-nek nevezték (1295: Parvi Gymus). Knyezsic határában említi a Garamszentbenedeki alapítólevél interpolált része a Saracska patak nevét (1075/+1124/+1217: Sarraczka), amelynek nyelvi azonosítása bizonytalan, talán a magyar sár földrajzi köznév képzős származéka (TóTH V. 2001a: 231, SzÖKE 2015: 192-193). A nagyobb patakok nevéhez hasonlóan bizonyára viszonylag szélesebb körben ismerhették a Csáki út nevet (1327: Czhaky ut) is, amely a Zsitva és a Garam völgyét kötötte össze. Előtagja a Bars vármegyében birtokos Csák nemzetségre utal (TóTH V. 2001a: 186).

A mikrotoponimák jó részét többnyire csak egy-egy település lakossága ismeri. Ebből adódóan az adott névközösség (azaz egy-egy település lakossága) aktuális nyelvhasználatát legközvetlenebb módon ez a helynévfajta tükrözi. Az egyes településekről rendelkezésünkre álló mikronevek a nyelvi eredet tekintetében nagyfokú egynemúséget mutatnak. Egyedül a kiterjedt hegyvidéki területekkel rendelkező Gímes határában találhatók szláv és magyar eredetủ nevek is. Kétségkívül szláv eredetủ a Divény hegy neve (1253: Dyun), amely szláv nyelvterületen többfelé előfordul. KISS LAJOS az összláv *divbjb 'vad' melléknév származékának tartja (FNESz. Nagydivény), ebből az -inъ helynévképzővel alakulhatott 
(ŠMILAUER 1970: 28-31, 55). Etimológiája alapján szláv és magyar eredetű egyaránt lehetne a Piliske hegy neve (1253: Plyska, 1295: Piliske), mivel az alapjául szolgáló szláv tô, a *plěšb 'kopasz (hegytető)' pilis formában a magyarba is átkerült (FNESz. Pilis). Az első névadat hangalakja azonban inkább szláv névadókra utal mind a szókezdő mássalhangzó-kapcsolattal, mind pedig a $-k a(<$ összláv -ъka) képzővel (ŠMILAUER 1970: 28-31, 143). A 13. század végéről való adat palatális hangsora viszont már magyar névhasználókat jelez. Magyar alkotású név a Szudina-fö (1295: Zudynefew), amelynek előtagja a szláv *studbńa, szlovák studňa 'forrás' földrajzi köznév (ŠMILAUER 1970: 172), illetve bizonyára egy belöle alakult szláv helynév. Forrás neve lehetett a Köz-patak-fö (1295: Kuzpotocfew), jellegzetes hegyvidéki mikronév a Kis-Köved (1295: Kuskued), s ezek mellett még a Keresztút (1253: keruztvth) nevet ismerjük Gímes határából. Szelepcsény lakóinak - noha a település neve szláv eredetü — magyar nyelvüségét mutatják az itteni mikronevek: Eresztvény, Poklos-verem, Majs gája (1234/1364: Erezthwen, Poklos uerem, Moys Gaya). Ez utóbbi névben a személynévi előtag a magyarba is átkerült szláv eredetü gáj 'erdő, liget' jelentésü földrajzi köznévhez kapcsolódhatott (TÓTH V. 2001a: 194, 220).

A magyar nyelvből származó mikronevek többségét olyan településekröl ismerjük, amelyek magyar eredetü nevet viselnek. Hizér határában Hizér-berek nevü (+1209/17. sz.: Hizerberek) erdőt említenek, Bélád határában Bérc ([127290]: Beerch), illetve Teknös nevü völgy ([1272-90]: Tekeneus) szerepel, továbbá az ismeretlen eredetü nevet viselö Vitazla völgy ([1272-90]: Witazla). Aha határában Berek (1265: Beruk) és Haraszt (1265: Harast) nevü helyeket ismerünk, Harsányon pedig Szakadat-ot (1274: Zakadath). A Topolnyica patak Keresztúrhoz közeli forrását Topolnyica-fó-nek (1293: Topolniche fev) nevezték.

5. A fentiekben áttekintettük azokat a helynévi adatokat, amelyek a Zsitva völgyéből a korai ómagyar korból, azaz a 14. század közepe előtti időből fennmaradtak. Ebből az időszakból e nyelvi elemfajtán kívül a térségből csupán személynévi adatokkal rendelkezünk. Ezek tanúsága — sajátos nyelvi jellegük miatt - a tényleges nyelvhasználati viszonyokat illetően jóval kevésbé vehető figyelembe, mint a helyneveké, így vizsgálatuktól eltekintettem. (A nyelvi viszonyok elemzésébe való bevonásukhoz az eddig alkalmazott módszertan jelentős megújítására is szükség volna. Ennek elméleti hátteréül a régi magyar személynévadás új szemléletü tárgyalása szolgálhat, amihez lásd TóTH V. 2016.)

Az alábbiakban a Zsitva völgyének nyelvi viszonyait tehát a helynevek tanúsága alapján kísérelhetjük meg jellemezni. Ehhez kiindulásként célszerü áttekinteni azokat az eredményeket, amelyeket e témában a magyar tudományosság elsősorban a nyelvtudomány és a történettudomány egyes részdiszciplínái - az eddigiekben közzétettek. Összességében megállapítható, hogy ezek az ismeretek meglehetősen gyérek és bizonytalanok, továbbá bizonyító anyagukat illetően is 
szegényesek s olykor elavultak. Meg kell jegyeznünk, hogy a korábbi munkák általában is és nem csak e térségre vonatkozóan — többnyire etnikumokról szólnak, de valójában nyelvekröl, nyelvhasználókról fogalmaznak meg következtetéseket. Ez a leegyszerüsítés nem veszi figyelembe az etnikum és a nyelv bonyolult összefüggésrendszerét, ám ezt egy évezred időtávlatában nem is könnyü megtenni. Mivel az etnikumokra vonatkozó korábbi vizsgálatok is jórészt helynévanyag alapján folytak, ezért ezek megállapításait összevethetőnek tartom az általam hangsúlyozottan nyelvi síkon elvégzett vizsgálatok eredményeivel.

E kérdésben KNIEZSA IsTVÁN kutatásai játszottak meghatározó szerepet. A Magyarország népei a XI. században címü munkájában közölt eredményeire és az ott alkalmazott módszereire alapoznak a későbbi munkák is. KNIEZSA a 11. századi Bars vármegyei viszonyokról azt állapította meg, hogy ,a tiszta magyar nyelvterület" északi határa a Zsitva melletti Verebély és a Garam melletti Bars vonalán húzódott, s e vonaltól északra „egy széles sávot találunk, amelyen vegyes magyar-tót lakosságot igazolhatunk" (1938: 376). A Nyitra és a Zsitva közti területen ez a vegyes sáv Lédec, Knyezsic és Aranyosmarót magasságáig terjedt. A 11. századi nyelvi helyzetre vonatkozó megállapításait 17 helynévi adatra alapozza, ezek közül azonban csupán négy való a 11. századból, a Garamszentbenedeki alapítólevélből, további négy a 12. század legelejéről, a zobori oklevélből, a többi név csak a 12-13. században fordul elő először (közülük kettő a Garamszentbenedeki alapítólevél interpolált részében). Az adatok nagy része településnév, de négy víznév és egy hegynév is van közöttük. KNIEZSÁnál kilenc név igazolja a magyarság jelenlétét (Keszi, Gyarmat, két Kürt, Besenyö, Füss, Zsitva-tő, Tormás, Saracska), hat a szlávokét (Kosztolány, Knyezsic, Taszár, Zsitva, Dervence, Tribecs), kettő pedig mindkét nyelv jelenlétére bizonyítékként szerepel (Marót, Lédec).

GYÖRFFY GYÖRGY a történeti földrajzában csupán azt állapítja meg, hogy „a helynevek tanúsága szerint szláv lakosság föként az erdő és a síkság peremvidékén élt" (Gy. 1: 414). Ennek igazolására 15 szláv eredetü nevet sorol fel (Zsitva, Tribecs, Dervence, Topolnyica, Rohozsnica, Kosztolány, Lédec, Tapolcsány, Knyezsic, Kelecsény, Nemcsény, Taszár, Szelepcsény, Tajna, Verebély), további kettőhöz pedig kronológiai értéket is hozzákapcsol: Szelezsény korai adatának az általa ôsszláv nazális magánhangzóra visszavezetett nazálisa szerinte ,igen korai szláv telepítésre mutat, ami vagy a X. századi kalandozó hadjáratokkal, vagy István király hospestelepítéseivel hozható kapcsolatba" (i. h.). Hasonló korú telepítés emlékének tartja (Aranyos)Marót nevét is. A Zsitva alsó völgyéről pedig azt állapítja meg, hogy „A magyarság 900 táján foglalta el a Kisalföldet és a D-i lankás-sík vidéken telepedett meg.” (i. h.). Ezt az állítást azonban konkrét érvekkel nem támasztja alá. Másutt — egy kissé más hangsúlyokkal — az alábbiakról szól: „A helynévanyag tanúsága szerint a síkvidék zömmel magyar, a hegyvidék 
túlnyomórészt szláv lakosságú; vegyes lakosság élt a hegy és síkság érintkező területén és a nagy folyók völgyében” (Gy. 1: 423).

KISS LAJOS az Árpád-kori Magyarország földrajzi és társadalmi arculatát áttekintő tanulmányában lényegében véve megismétli GYÖRFFY idevágó megállapításait, csupán annyit módosít azokon, hogy Verebély nevét kiiktatja a szláv eredetü, szlávokra utaló nevek közül (1988).

Elméleti szempontból e kérdéskörben KRISTÓ GYULÁnak a középkori Magyarország nem magyar népeit bemutató monográfiája a legtanulságosabb. Az északi hegyvidék népesedési viszonyairól általában véve azt állapítja meg, hogy „Itt a szlávság egy része túlélte a magyar honfoglalást, és a 11. századtól kezdődően erre a szláv etnikumra rétegződött rá az egymásra torlódó telepítések révén az újabb és újabb szláv népesség.” (2003: 90). Ezt a helyzetet Bars vármegyére vonatkozóan is érvényesnek mondja, mivel szerinte „Barsban szintén megtalálható a magyar honfoglalás előtti időre visszavezethető, de legalábbis igen korai szláv helynévréteg" (2003: 95-96). Arról azonban nem szól, hogy az itt megadott időhatárok (a honfoglalás előtti és azt követő ,igen korai” időszak, illetve a 11. század mint a betelepítések kezdete) milyen tényezők alapján állapíthatók meg, de vélhetően nyelvészetiekre gondol, mivel az ,igen korai szláv helynévréteg”-et említi mintegy bizonyítékként. Arról is szól, hogy a megye legészakibb részének szlávokkal való betelepítése már „korán (alkalmasint a tatárjárást megelőzően) elkezdődhetett" (2003: 96). Ehhez szláv eredetü településneveket (Hrussó, Ebedec) hoz fel igazolásként. Az itteni telepek jó részét a betelepülőkhöz köti, de véleménye szerint néhány a szláv őslakossághoz is kapcsolható. Kronológiai vonatkozású állításaihoz azonban egyetlen esetben sem füz bizonyító adatokat vagy más magyarázatokat.

Ezt annál is inkább furcsának vélhetjük, mivel munkájában az itteni szlávokkal kapcsolatos problémát általánosságban az alábbiak szerint látja: „A nagy dilemma tehát az, hogy miként tudjuk elválasztani az »őslakosokat« és a bevándorlókat. Zsinórmérték vagy afféle különleges mágnes, amely automatikusan jelzi ezt, nem áll rendelkezésünkre.” (2003: 89).

Ez utóbbi gondolattal teljesen egyetértve az alábbiakban megpróbálom felvázolni azt a képet, amelyet a Zsitva völgyének korai ómagyar kori nyelvi viszonyairól az akkori helynevek alapján meg tudunk rajzolni.

6. A fentiekben elvégzett elemzések alapján egyértelmüen megállapítható, hogy a Zsitva völgyében található korai ómagyar kori helynevek szláv és magyar nyelvü népesség jelenlétére utalnak. A nevek alapján meg lehet kísérelni, hogy meghatározzuk ezek területi és egymáshoz való kronológiai viszonyát s lehetőség szerint mindezek időbeli változását is. Ez a nevekben megmutatkozó nyelvi kölcsönhatások elemzésével valósítható meg leginkább. 
A nevek keletkezési idejéről sajnos nem tudunk nyilatkozni, azaz abszolút kronológiát nem tudunk felállítani, mivel nincs olyan eszközünk, amelynek a segítségével az ómagyar kori nyelvi elemek — jelen esetben helynevek — létrejöttének az idejét pontosan meg lehetne határozni. Következtetésünk alapjául csakis a rendelkezésünkre álló adatok szolgálhatnak, mivel nem fogadhatjuk el azt a helynevekre vonatkozóan kialakított, korábban általánosan alkalmazott felfogást, amely bizonyos névtípusokhoz — a bennük megmutatkozó szemantikai és részben morfológiai jegyek alapján — valamiféle általánosan érvényes, az adatolástól független kronológiai paramétereket rendel hozzá (ehhez lásd HOFFMANN-TÓTH 2016).

Nagyon óvatosan lehet csak alkalmaznunk azt az általános nyelvtörténeti alapú módszertani eljárást is, amely a nevekben feltárható hangtani, morfológiai, lexikális jelenségeket a kronológiai meghatározás biztos, megingathatatlan alapjának tekinti, mivel ezeket az általános ismereteket is magából a forrásanyagból vonta le következtetésként korábban a tudományos elemzés. Ha pedig ezek fényében értékeljük (újra) az adott esetben vizsgálat alá vont adatokat, akkor a felhasznált tudásanyagot sem tudjuk meghaladni, vagyis elzárjuk az általános nyelvtörténeti tudásunk folyamatos korrekciójának a lehetőségét, éppen azt, amit az adott esetben elvégzett és ehhez hasonló vizsgálatok révén gondolunk megvalósíthatónak. Legtöbb eredménnyel ennek következtében az adatok egymáshoz való viszonyításának, szembesítésének a módszere kecsegtet bennünket.

A Zsitva völgyét a magyar, illetve a szláv nyelvböl származtatható helynevek alapján meglehetősen határozottan elkülönülő két térségre oszthatjuk. E két terület határa Verebélytől kissé északra található, s nagyjából kelet-nyugati irányban szeli ketté a folyóvölgyet. Ezt — ahogyan fentebb láthattuk — lényegében így állapította meg KNIEZSA ISTVÁN is, majd az ő nyomán bővebb adatállománnyal alátámasztva GYÖRFFY GYÖRGY is igazolta. Ez a két térség — amint azt írásom bevezető részében is jeleztem — természetföldrajzi szempontból is eltérő jellegü, aminek a középkorban az ott élők életmódjára is meghatározó befolyása lehetett.

A folyó völgyének alsó, déli térségében a Zsitva nevének kivételével csakis magyar eredetü helynevek (településnevek és mikronevek) találhatók. Még a bizonytalan eredetüek (Fedémes, Örs) is kétségkívül a magyarból valók, mindössze két településnevet minősíthetünk ismeretlen eredetünek (Peced $\sim$ Peted, Oboz), de ezek megfejtése is — az egynemü névkörnyezetük alapján — valószínüleg a magyar nyelvben kereshető leginkább. Paradox módon a két betelepülő népességre utaló településnév (Besenyö, Tót) is a magyar nyelvü környezetet igazolja, az ide betelepülők nyelvi helyzetéről azonban nincs tudomásunk, az utóbbi települést később nem is említik a források.

Az első forrásadatok ebből a térségből 1075-ből, a Garamszentbenedeki alapítólevél 11. századhoz köthető részéből valók, ám ezek a magyarság itteni megtelepülésének idejére vonatkozóan aligha szolgálhatnak támpontul. Erről a kérdésröl nyelvi adatok, nyelvészeti módszerek alapján sajnos nem tudunk nyilatkozni. 
Leginkább abban bízhatunk, hogy a térség korabeli régészeti anyagának az itteni nyelv- és névtörténeti elemzéshez hasonló szisztematikus áttekintése nyújt majd olyan megbízható, korszerü ismeretanyagot, amit aztán megkísérelhetünk összekapcsolni a nyelvi adatokból származó információkkal.

A Zsitva nevének szláv eredete és környezetének magyar nevei önként kínálják azt a lehetőséget, hogy ezt a névmintázatot esetleg megfeleltessük a Bakonyalján tapasztaltaknak. Ott is azt állapítottuk meg ugyanis, hogy a szláv eredetü nevet viselő patakok (Gerence, Tapolca, Bitva, Torna) völgyében — legfeljebb egy-két, többnyire bizonytalan kivételtől eltekintve - magyar településnevek találhatók. Ez a névmintázat ott kétségtelenül arra utal, hogy a magyarság rátelepült a térségben talált szláv nyelvú népességre, amely aztán később nyelvében magyarrá vált. Vajon nem ugyanez vagy ehhez hasonló folyamat zajlott-e le a Zsitva alsó völgyében is?

Ez a lehetőség nem zárható ugyan ki, de a névmintázatok lényeges különbségei alapján nem is nagyon valószínüsíthető. A Zsitva nevét ugyanis - a továbbiakban kifejtettek szerint - feltehetően nem ebben a térségben, hanem ettől északabbra ismerhette meg a magyarság az ott élő szláv nyelvü népességtől: a folyónév szláv eredete alapján tehát a völgy alsó térségében nem kell szláv nyelvü lakosságot feltennünk. Minthogy emellett a kisebb folyóvizek nevei is mind a magyar nyelvből valók (Tormás, Nagy-ér, Szék-ér, Lüle pataka), nincs okunk azt feltételezni, hogy a Zsitva alsó völgyében a magyarság bármilyen ott élő más nyelvü népességre települt volna rá.

A magyar és a szláv eredetű nevek viszonya szempontjából teljesen más helyzetet tapasztalunk a Zsitva felső völgyében, beleértve az itteni mellékvizeinek a völgyeit is. A két névréteg arányait a Zsitva alsó és felső völgyében az alábbi két diagram mutatja.
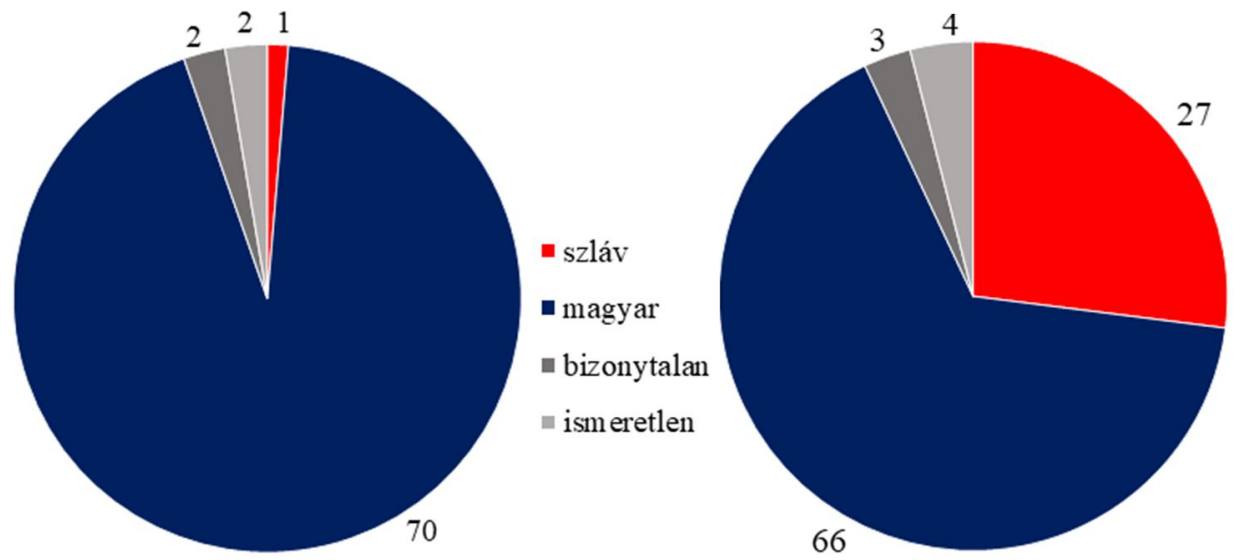

2. ábra. A magyar és a szláv eredetü nevek viszonya a Zsitva-völgy alsó (1. diagram) és felsö (2. diagram) részén 
A Zsitva felső térségében tehát magyar és szláv eredetű nevek is találhatók, $\mathrm{s}$ a korai ómagyar kor egészére vonatkozóan a magyar nevek száma csaknem a két és félszerese a szlávokénak. Erről a területről nemcsak a ránk maradt nevek száma nagyobb, hanem valamivel több településröl (65) is tudomásunk van, mint a folyóvölgy jóval hosszabb alsó részén (53).

Amint azt a Zsitva nevének elemzése kapcsán jeleztem, szemantikai tartalma alapján valószínúsíthető, hogy a víznév itt, a felső völgy délebbre eső szakaszán, a Verebély és Marót közti részen keletkezhetett. Ezt a feltevést a szláv eredetü településnevek térbeli eloszlása és valamelyest az adatolásuk kronológiai paraméterei is alátámasztják. A 3. és a 4. ábra két térképe a Zsitva felső völgye szláv és magyar eredetü településneveinek, illetve természeti neveinek a megoszlását ábrázolja.
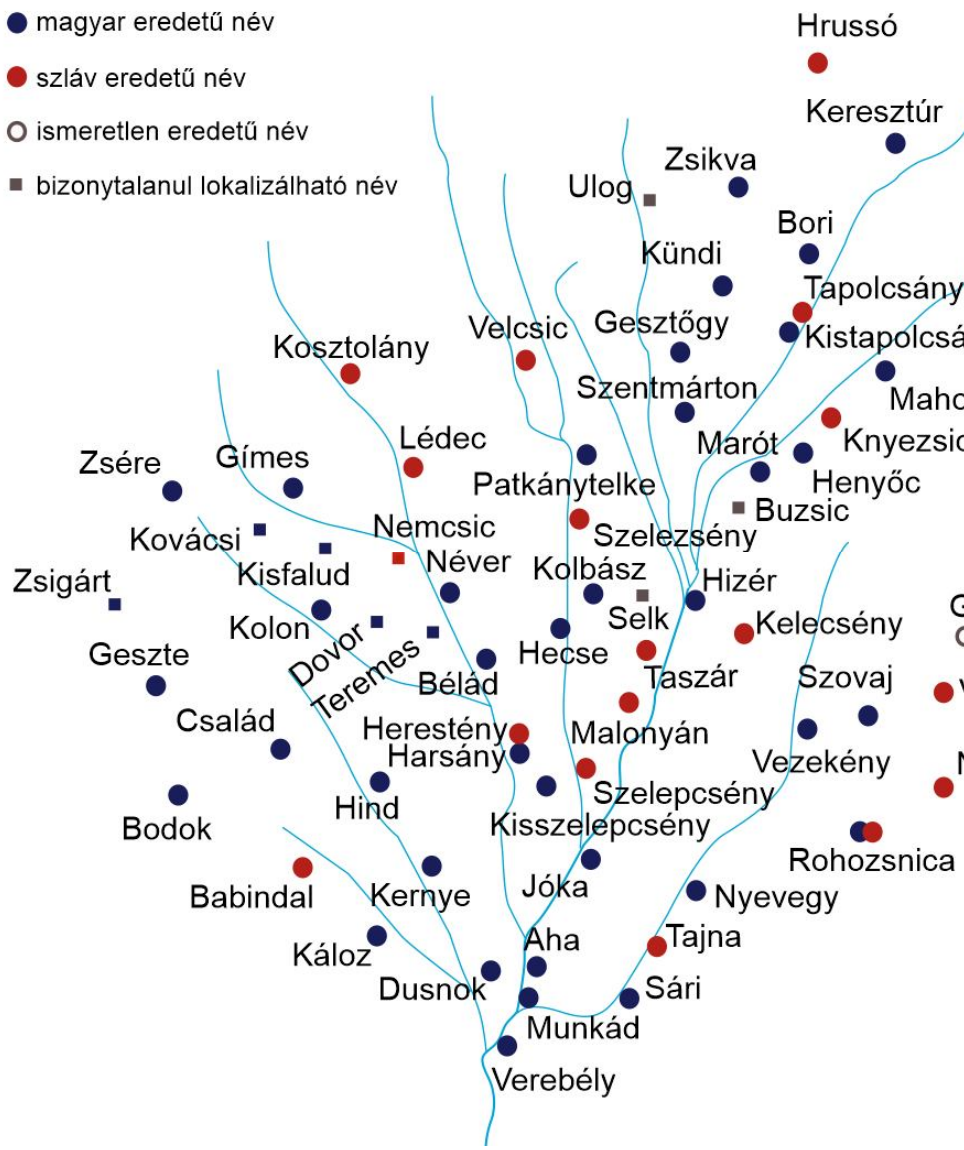

3. ábra. A Zsitva felsö völgye korai ómagyar kori településneveinek eredetbeli megoszlása 


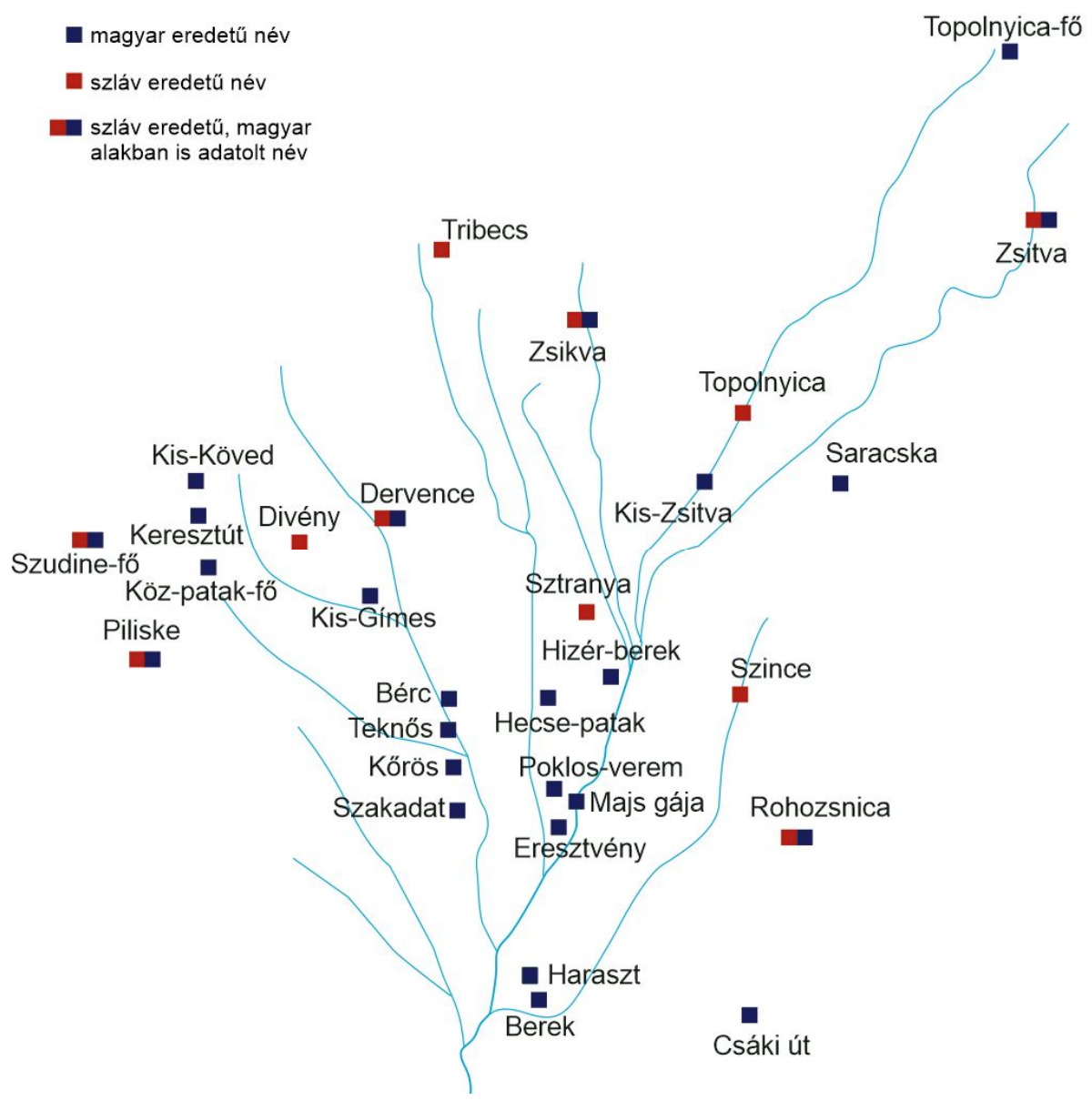

4. ábra. A Zsitva felsö völgye korai ómagyar kori természeti neveinek eredetbeli megoszlása

A jelzett szakaszon több szláv eredetü településnév szerepel (Taszár, Maholány, Szelepcsény), továbbá Marót mellett északra Knyezsic, de ide vonható a folyóhoz egészen közel fekvő Kelecsény is. A térség adatolási viszonyai között ezek kifejezetten korai előfordulású neveknek számítanak: 1075 és 1209 között említik őket először. A Zsitva más szakaszán szlávból származó településnevet egyáltalán nem is találunk (legfeljebb a bizonytalan etimológiájú Ebedec $\sim$ Ebic neve jöhet szóba az itt említettektől kissé északra). Mindez megítélésem szerint azt is jelzi egyúttal, hogy a Zsitva völgyébe megérkező és itt megtelepülő magyarság ebben a térségben találkozhatott először a szlávsággal, és vette át tölük a Zsitvának és a szlávok településeinek a megnevezéseit.

A két nép találkozásának az idejéről nyelvészeti eszközök segítségével nem tudunk semmi közelebbit mondani (az adatolás ebben a kérdésben is csupán mint 
ante quem meghatározás vehető figyelembe). Ez esetben is a régészeti és a helynévi adatok tanulságainak az összevetésétől remélhetünk pontosabb ismereteket. Ennek jelen esetben nem csupán településtörténeti jelentősége lehetne, hanem fontos magyar hangtörténeti tanulságokkal is járhatna, mégpedig a [zs] hang történetét illetően. A [zs] hang ugyanis a magyar hangtörténetírás egybehangzó véleménye szerint idegen nyelvi (föleg szláv) átvételek hatására honosodott meg a magyar nyelvben, amelyhez belső nyelvi jelenségek (szótagszerkezeti változások, a zöngésség szerinti hasonulás) is hozzájárulhattak (BÁRCZI 1958: 112, E. ABAFFY 2003: 313-314, GERSTNER 2018: 115-116). A [zs] magyar nyelvbeli megjelenésének az idejével kapcsolatban a szakirodalom — források híján és a hang jelölési problémáiból is következően - nem nagyon foglal állást, de inkább azt sugallja, hogy ez hosszabb, elhúzódó folyamat lehetett. Az a körülmény, hogy a Zsitva neve a magyarban [zs]-vel hangzik, azt jelzi, hogy a magyarba ez a név ezzel a hanggal került be a szlávból, és nem hanghelyettesítéssel történt az adaptációja. A korai adatok a helyesírás kiforratlansága miatt e kérdésben nem mérvadók, ugyanis a magyar helyesírásban sokáig nem különült el a [zs] és az [s] hang jelölése. Az érintkezés idejének a meghatározása tehát a [zs] magyar nyelvbelilegalábbis az itteni nyelvjárásbeli — meglétének a kérdésében is perdöntő lehetne. Ez a problémakör érinti a [zs]-t tartalmazó további Zsitva-völgyi helynevek (Knyezsic, Szelezsény, Zsikva) ügyét is.

Az a körülmény, hogy a Zsitva felső völgyében a szlávság a magyarok betelepülését megelőzően is jelen volt, aligha lehet kérdéses. Ezt a Zsitva nevének átvételén kívül elsősorban az itteni folyónevek szláv eredete bizonyítja. Közülük legjelentősebb a Bars és Nyitra vármegye között határként szereplő Dervence, amelynek a felső folyása mentén fekvő három település (Kosztolány, Lédec, Nemcsic), valamint a velük határos Velcsic neve szláv eredetü. Ebbe a szláv névkörnyezetbe sorolható a térséggel nyugatról szomszédos Gímes határában említett két szláv eredetü hegynév, a Divény és a Piliske is, valamint a Dervence forrásvidékénél fekvő Tribecs hegység neve.

A folyóvölgy alsó részén magyar településnevek (Néver, Bélád, Harsány) utalnak a betelepülö magyarságra. A víznév átvételéből arra következtethetünk, hogy az itteni szláv telepek régebbiek a magyarokéinál. A Dervence völgyének és a Zsitva völgyének fentebb említett szláv nevü települései között fekszik Szelezsény, amelynek a neve - mint azt korábban bemutattam — sziléziai betelepülőkre utal. E betelepülés a magyarság itteni megjelenését megelőzően történhetett, amit a falu — nyilvánvalóan a környező népesség által adott — nevének szláv eredete jelez. A szlávok korai ittlétére utal a falu határában folyó Sztranya patak szláv eredetü neve is.

A Dervence folyásától nyugatra, a Nyitra vármegyéhez tartozó részen magyar eredetű településneveket találunk, és magyarok (a fenti kettő kivételével) az itteni 
mikrotoponimák, köztük a víznevek (Körös, Kis-Gémes, Köz-patak) is. A településnevek között az egyetlen szláv eredetủ név Babindal-é, amely mikronévből keletkezett, és egy feltehetően magyar eredetủ $B a b a$ településnévre megy vissza. Ennek igazolása azonban további településtörténeti vizsgálatokat kíván. Ez esetben Babindal neve a magyarok közé betelepülő szláv népességre utalhat ugyanúgy, mint a közeli Herestény-é is (ezt lásd alább). A Szelezsénnyel szomszédos Marót neve ugyancsak szláv betelepülőket jelez, a településnév magyar népnévvel (morva, illetve marót) való megjelölése azonban azt mutatja, hogy a morva telepesek ide már magyar környezetbe érkeztek.

A Zsitva mentén található, szláv eredetü nevet viselö, fentebb tárgyalt települések térségéhez közvetlenül kapcsolódik a Zsitva mellékvizének, a szintén szláv nevü Topolnyicá-nak a völgye. A víznéven kívül a folyó mellett fekvő Tapolcsány neve is a szlávból való, mindkettő - kései adatolásuktól függetlenül — arra utalhat, hogy a szlávság ezen a területen is megelőzhette a magyarságot. Ha ez nem így lett volna, nem tudnánk választ adni arra a kérdésre, hogy a környékbeli magyar nevet viselő települések vélhetően magyar nyelvü lakossága kitől vette volna át a folyóvíz szláv eredetủ nevét. A térség legészakibb településének, Hrussó-nak a neve talán csak azt követően került át a magyar nyelvbe, hogy lezajlott a szlovák $g>h$ változás. Ez pedig valószínüleg azt jelzi, hogy a település esetleg csak a 12. század után létesülhetett, ugyanis a szomszédságában található magyar nevet viselő Zsikva településre már a 11. század végéről van adatunk. Ha Hrussó már ekkor létezett volna, a neve [g]-vel kezdődő formában került volna át a magyarba. A név magyar adaptációját változatos alakok (Hurusó, Hursó) jelzik. Ez esetben sem lehet azonban kizárni azt a lehetőséget — amelyet alább, a Rohozsnica név kapcsán mutatok be - , hogy a település korábbi ennél, és a $h$ val kezdődő névforma a folyamatos nyelvi érintkezés révén rögzült a magyar nyelvben. A víznevek esetében ez azonban talán valamivel nagyobb eséllyel vethető fel.

A Zsikva baloldali mellékvizeinek, a szláv eredetü nevet viselő Rohozsnicának és a Szincé-nek a völgyében ugyancsak találunk szláv eredetű településneveket (Valkóc, Nemcsény, Tajna és esetleg Rohozsnica település). A víznevek tanúsága arra vall, hogy a szlávok ezen a területen is jelen lehettek már a magyarok megjelenése előtt. A hagyományos nyelvtörténeti felfogás szerint gondolkodva — és elfogadva a szlovák $g>h$ változás időszakának a 12. századot — a Rohozsnica név átvételét a legkorábban a 12-13. század fordulójára vagy legfeljebb a 12. század második felére tehetnénk. Ez azt is jelenti, hogy a magyarság itteni megjelenésének idejét is erre az időszakra kellene helyeznünk, aminek a környékbeli magyar eredetủ településnevek legkorábbi, a 13. század elejétől adatolható előfordulása meg is felelne. (A tágabb környezetben ugyanakkor jóval korábban megjelenek a magyar településnevek.) Ez a fajta nyelvtörténeti gondolkodás 
azonban valójában nem vesz tudomást arról, hogy az egymással tartósan szomszédságban élő nyelvek használói - döntően egy kétnyelvü réteg közvetítésével - folyamatosan kapcsolatban állnak egymással. Így például a kérdéses nevet akár már korábban — amikor a szlávban még [g]-vel hangzott — is átvehette a magyarság, de a folyamatos nyelvi kapcsolat révén a szlovák nyelvbeli hangtani módosulását követhette a magyarok által használt forma hangalakjának a megváltozása is.

Ez az érvelés elsőre akár ellentétesnek is tünhet azzal a megközelítéssel, amellyel a Zsitva nevének [zs]-vel való átvételét magyaráztam, valószínútlennek tartva egy korábbi, hanghelyettesítéssel való átvétel lehetőségét. A Zsitva esetében azonban a nevet átvevő és használó magyarság jelentős csoportja — lényegében a folyóvölgy alsó szakaszán élők — nem volt közvetlen kapcsolatban szlávokkal. Ugyanez magyarázza (ráadásul ugyancsak a $g>h$ változás eseteként) a Garam nevének magyar nyelvü alakját is: a magyar nyelvhasználók szélesebb köre az átvételt követően már nem állt nyelvi kapcsolatban az átadó szláv nyelvü népességgel, ezért a magyar névalakban nem érvényesült a szlovákban később lezajlott $g>h$ változás (a Garam nevéhez lásd FNESz., TÓTH V. 2001a: 195196, SzÖKE 2015: 169-170).

Az a nyelvi kölcsönhatás, amely a Rohozsnica alakulásában feltehetö, de nem adatolható, más oldalról adatokkal is igazolható Herestény település névváltozataiban. A falunak a 13. század végéig csak a magyar eredetü Harsány nevét ismerjük, mégpedig magyar névkörnyezettel, vagyis két itteni magyar mikronévvel (Körös, Szakadat) és a szomszédos települések magyar eredetü neveivel (pl. Bélád, Néver, Hind, Bodok, Család) együtt. A századforduló környékén azonban feltünik a szláv eredetü Harasčan Harastan név is, amely szláv növénynévböl való képzés, de kialakulására hathatott a település magyar nevének a hangzása is. Már ezzel egy időben jelentkezik a név Herestény változata is, amely a magyar nyelvben lezajlott hangtani adaptációt jelez. A Harsány névforma később nem is fordul elő. Mindezek alapján valószínü, hogy a magyarok mellé itt szlovákok települtek, és ezt követően a két nyelvközösség egymással nyelvi kölcsönhatásban élt, $\mathrm{s}$ ez alakította - egymáshoz igazodóan — a település nevének módosulásait. Ugyanilyen jellegü nyelvi kapcsolatra utalhat az is, hogy Taszár neve sokáig váltakozva tünik fel eredeti szláv (vegyes hangrendü) alakjában s emellett magyar nyelvü palatális és veláris formában is.

Amint azt már korábban jeleztem, nyelvészeti bizonyítékaink, érveink nincsenek arra vonatkozóan, hogy a magyarok mikor népesítették be a Zsitva felső völgyét. Az azonban figyelemreméltó körülmény, hogy e térség legészakibb, hegyvidéki részén már 1075-ben feltủnik Zsikva település, amelynek a neve nagy valószínüséggel magyar névadókra utal. A Zsikva, a Topolnyica és a Zsitva itteni szakaszának környezetében néhány kivétellel magyar eredetü településnevek 
szerepelnek. A Dervencétől nyugatra fekvő, már korábban említett nyitrai részek mellett ez a térség mutatja a magyarság felső Zsitva-völgybeli jelenlétének legnagyobb sürüségét. A többi térségben, a Dervence és a Zsikva közötti sávban és ennek délkeleti folytatásában, a Rohozsnica vidékén azonban vegyesen fordulnak elő magyar és szláv eredetü helynevek. Ahogyan a fentebb mondottakból kitünik, a szlávok itt jórészt megelőzték a magyarságot, és a betelepülő magyarok a szláv települések közötti területeken hozták létre falvaikat.

A korábban hivatkozott munkáimban hasonló helyzetet mutattam be a Bakonyalja térségben, ám ott a magyarság nem vette át a kétségkívül ott élő szlávok településneveit, hanem maga nevezte el a falvait. Az itteni felső Zsitva-völgyi névmintázat viszont egymás mellett tartalmaz szláv és magyar településneveket is. Erre a nyilvánvaló különbségre egyelőre nem tudok magyarázatot adni. Ennek oka lehet időbeli eltérés, az adott nyelvhasználói csoportok létszámában mutatkozó különbség, de akár más, például birtoklástörténeti jellegü tényezők is meghúzódhatnak mögötte. Az okok feltárásában segítséget nyújthat az, ha további térségek névmintázatait hasonló módszerrel szintén áttekintjük. A kérdéskörben meghatározó jelentősége lehet a történettudományi és a régészeti kutatások legújabb eredményeivel való összevető elemzéseknek is.

A magyarok jelenlétét ezen a területen az itteni szláv eredetü további településnevek magyar nyelvi adaptációja is meggyőzően mutatja. Csaknem minden olyan név esetében jelentkezik valamilyen jellegzetes magyar hangtani változás, amelynek eredeti szláv hangszerkezete eltér a magyar nyelvben szokásos formáktól. Hat névben mutatható ki hangrendi kiegyenlítődés (Szelepcsény, Kelecsény, Nemcsény, Szelezsény, Kosztolány; Dervence), ugyancsak hat esetben pedig olykor csupán ideiglenesnek mutatkozva - szó eleji bontóhang betoldódása (Szelepcsény, Szelezsény, Knyezsic, Hrussó; Dervence, Piliske). Előfordul emellett a második szótag magánhangzójának labializációja (Velcsic, Lédec), a második szótag magánhangzójának kiesése (Zsitva), inetimologikus mássalhangzó betoldása (Nemcsény), magánhangzóközi [h] kiesése (Rohozsnica), $t>k$ változás (Zsikva), helynévképző adaptációja (Valkóc), morfémának felfogott névvégződés elvonása (Szelepcse). Néhány olyan névben nincs csak nyoma a hangtani adaptációnak, amelynek a hangzós jellege mindenben megfelel a magyar nevek hangtani struktúrájának (Malonyán, Tapolcsány, Tajna, Nemcsic, Babindal; Topolnyica, Szince). Csupán két olyan nevet találunk, amelyben nem következett be olyan jellegü hangtani adaptáció, amely a többi név változása, illetve általános hangtörténeti tapasztalatok alapján várható lenne (Tribecs, Sztranya).

Megjegyzendő az is, hogy a nevek túlnyomó többsége már első említésekor a magyar nyelvi adaptáció révén kialakult formájában szerepel. Ettől csupán néhány esetben van eltérés: a Zsitva jobb oldali mellékvizeinek felső szakasza mellett fekvő Kosztolány és Velcsic neve előbb szlávos alakban szerepel, és csak később 
tünik fel magyaros formában. Ez esetleg — a települések földrajzi helyzetével is összeegyeztethető - későbbi névátvételt is jelezhet.

Az 5. ábra térképén a felső Zsitva-völgy korai ómagyar kori településneveit a forrásokban való feltủnésük évével jelöltem meg. Pirossal szerepelnek a szláv, kékkel a magyar nyelvű névhasználókhoz köthető, szürkével a bizonytalan, ismeretlen eredetủ nevekre vonatkozó évszámok. A szláv eredetủ nevet viselő, piros körrel megjelölt települések mellett szereplő kék színü évszám azt jelzi, hogy a név csakis magyaros formában tünik fel a forrásokban. A szláv eredetủ neveknél kötőjellel összekapcsolt piros és kék színnel jelölt évszám pedig azt mutatja, ha szláv és magyar alakban is feltünik a név.

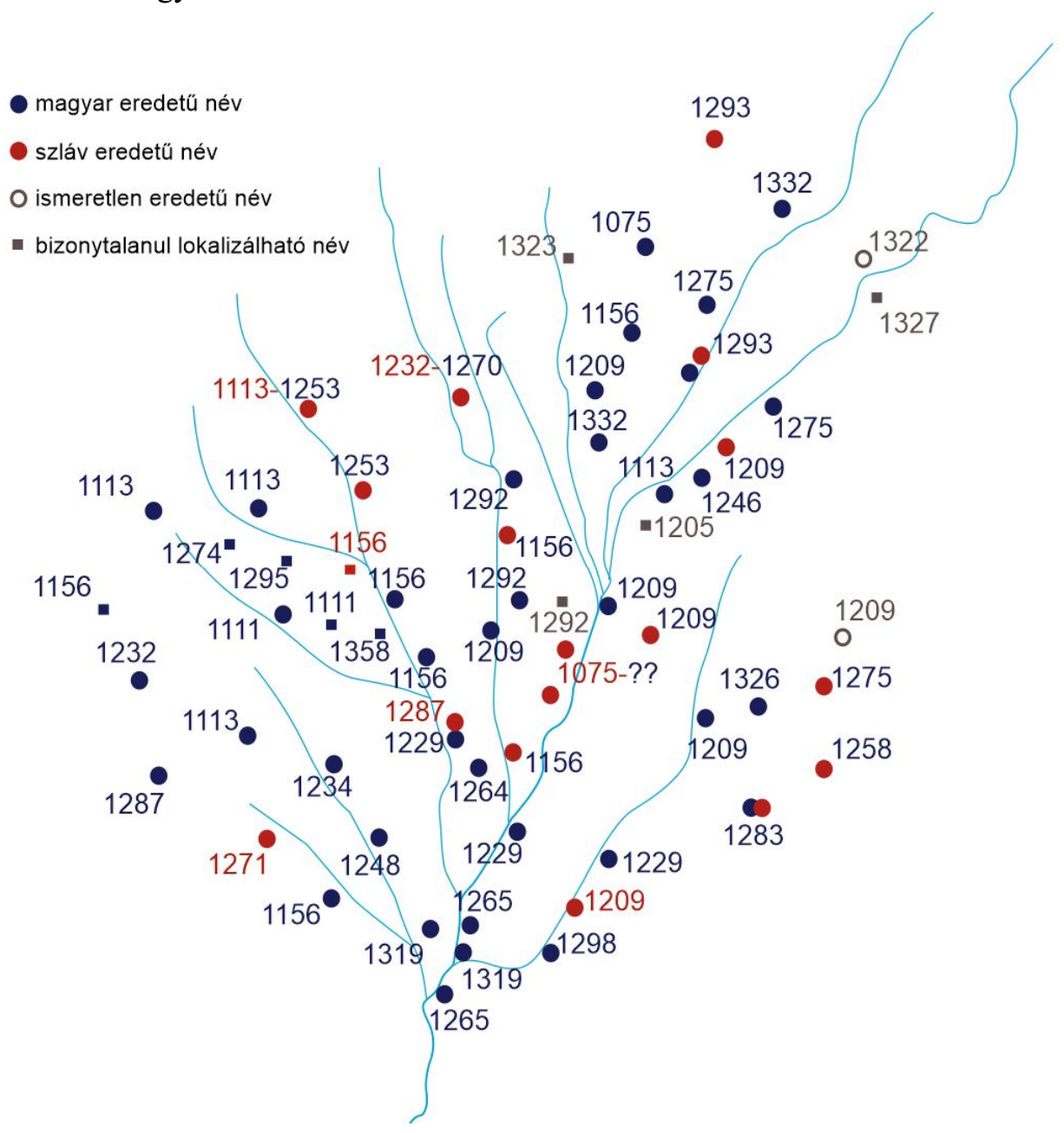

5. ábra. A Zsitva felsö völgyében feltünö településnevek kronológiája eredetbeli rétegek szerint 
A fentiekkel kapcsolatban felmerülhet az a kérdés, hogy a szláv nevek magyar nyelvi adaptációjára vajon milyen nyelvhasználói környezetben kerülhetett sor. Erre általános szocioonomasztikai ismeretek alapján adható elvi jellegü válasz. A nevek átvétele megtörténhetett olyan helyzetben, hogy az adott településen szláv és magyar nyelvü lakosság is élt. Megtörténhetett másrészt a névadó szláv népesség nyelvcseréje, magyar nyelvűvé válása révén is. Mindezek mellett az is elképzelhető, hogy egy-egy szlávok lakta település neve a környező településeken élö magyarság nyelvében adaptálódott. Az oklevelek létrehozásában közremüködő írnokok a Magyar Királyság nyelvi presztízsviszonyainak megfelelően többnyire magyar nyelven rögzítették a neveket (ehhez lásd HOFFMANN-RÁCZ-TÓTH 2018: 50-52). Ez pedig azt is jelenti természetesen, hogy a településnevek nyelvi jellegéből nem feltétlenül következtethetünk lakóinak nyelvi viszonyaira. Az egyes települések nyelvhasználatát jóval pontosabban, közvetlenebb módon jelzik viszont az ott használatban lévő mikronevek nyelvi formái.

7. A Zsitva-völgy korai ómagyar kori helynévmintázatát vizsgálva a figyelmemet a fentiekben elsősorban a térségben jelenlévő két nyelvnek, a szlávnak és a magyarnak az elemzésére, kapcsolatának a bemutatására fordítottam. Tanulságos lehet azonban ezt a vizsgálatot olyan megközelítésben is elvégezni, hogy annak középpontjában a magyar helynévrendszer áll. Ehhez abból a megfigyelésből indulhatunk ki, hogy a helynévminták időben változást, térben pedig változatosságot mutatnak. Így lehetőség adódik arra is, hogy egyes korok és térségek helynévmintázatainak az összevetése révén is jellemezzük a különböző nyelvhasználói csoportokat. Mindezt annak a tudatában tehetjük, hogy ezek a megfigyelések nem csupán a nyelvet érinthetik, hanem a magyarság általános történetének a megismeréséhez is hozzájárulhatnak.

Mivel a névmintázatok vizsgálata nem önmagukban, hanem az egymáshoz való viszonyításuk által adhat jól értékelhető eredményeket, az elemzést az alábbiakban — az összevetés lehetősége végett — a Bakonyalja névanyagán lefolytatott vizsgálati szempontot alkalmazva végzem el (HOFFMANN 2019: 21-26). Ennek során a magyar eredetü településnevek két nagy szerkezeti csoportját, az egy- és a kétrészes neveket különítem el, ezen belül pedig az egyes szemantikai csoportok arányait vizsgálom. (Az elemzés további szempontok bevonásával gazdagítható, itt azonban csupán az a célom, hogy felvillantsam a névrendszertani elemzés termékeny voltát.) Az alábbi diagram a Zsitva két térségében az egyes névtípusok arányát mutatja. 

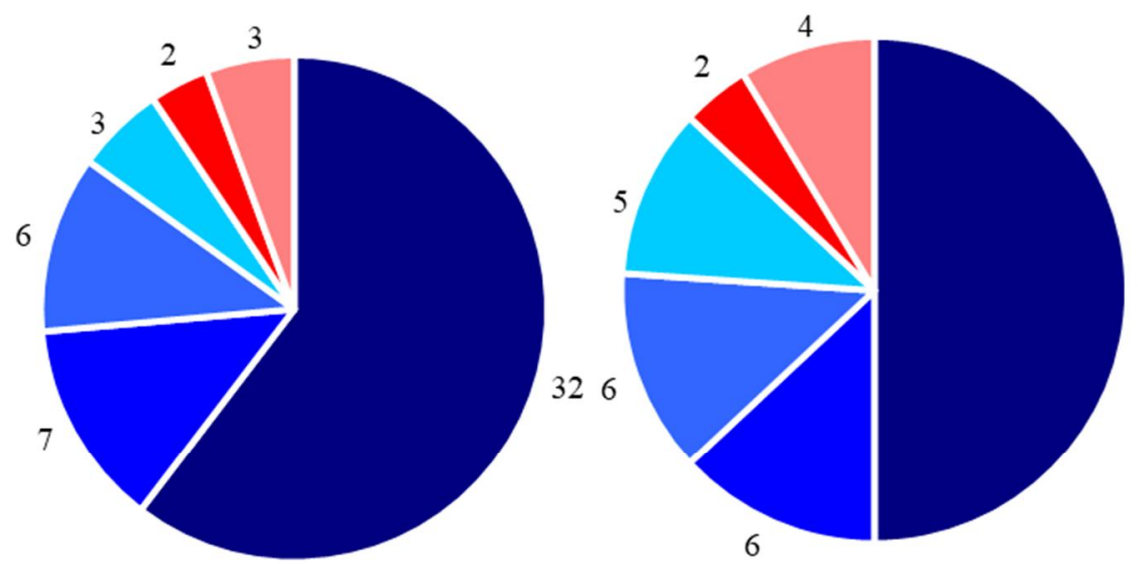

egyrészes nevek

- személynévből alakult településnév

- társadalmi csoportnévből alakult településnév

- természeti környezetre utaló településnév

- építményre utaló településnév

kétrészes nevek - földrajzi köznévi utótagú településnév

n településnévi utótagú településnév

6. ábra. A Zsitva alsó (1. diagram) és felsö (2. diagram) völgye magyar helynévtípusainak megoszlása

Megállapítható, hogy a Zsitva alsó és felső völgyének magyar névrendszere nagy fokú hasonlóságot mutat. Jelentősebb különbség mindössze a személynevekből alakult településnevek arányában mutatkozik: az alsó szakaszon a nevek 60\%-a tartozik ide, a felső részen pedig a fele. Számában nem, de arányaiban jelentős az eltérés az épített környezetre utaló nevek $(6 \%-11 \%)$ és a másodlagos, kétrészes településnévi alaptagú nevek (6\%-9\%) között. Ez összességében azt mutatja, hogy az alsó folyóvölgy névrendszere némileg archaikusabb jellegü, mint a felsőé: a személynévből alakult helynevek a társadalmi csoportnevekkel együtt ugyanis a településnév-rendszer legrégebbi rétegét adják, míg az épített környezetre utaló, valamint a kétrészes, különösen a másodlagos alakulású nevek a korai ómagyar kor második felében, sőt főképpen azt követően váltak jellegzetes névtípussá. A két névrendszerben megmutatkozó némi időbeli különbség mögött akár településtörténeti tényezők is állhatnak, erröl többet azonban a nevek elemzése alapján nem tudunk mondani.

Felvetődhet az a gyanú, hogy a névtípusokban megmutatkozó eltérés nem az adatolás esetlegességéből, egyenetlen időbeli eloszlásából adódik-e. Az alábbi diagramon azt látjuk, hogy a településnévi adatok feltünése milyen időbeli megoszlást mutat (fél évszázadonkénti bontásban). Ebből világosan kitünik, hogy a felső folyóvölgy forráshelyzete kronológiai tekintetben kedvezőbb, mint az alsóé, 
s ez egyúttal azt is jelzi, hogy ez utóbbi névrendszer archaikusabb jellege semmiképpen sem az adatok időbeli eloszlásával van összefüggésben.

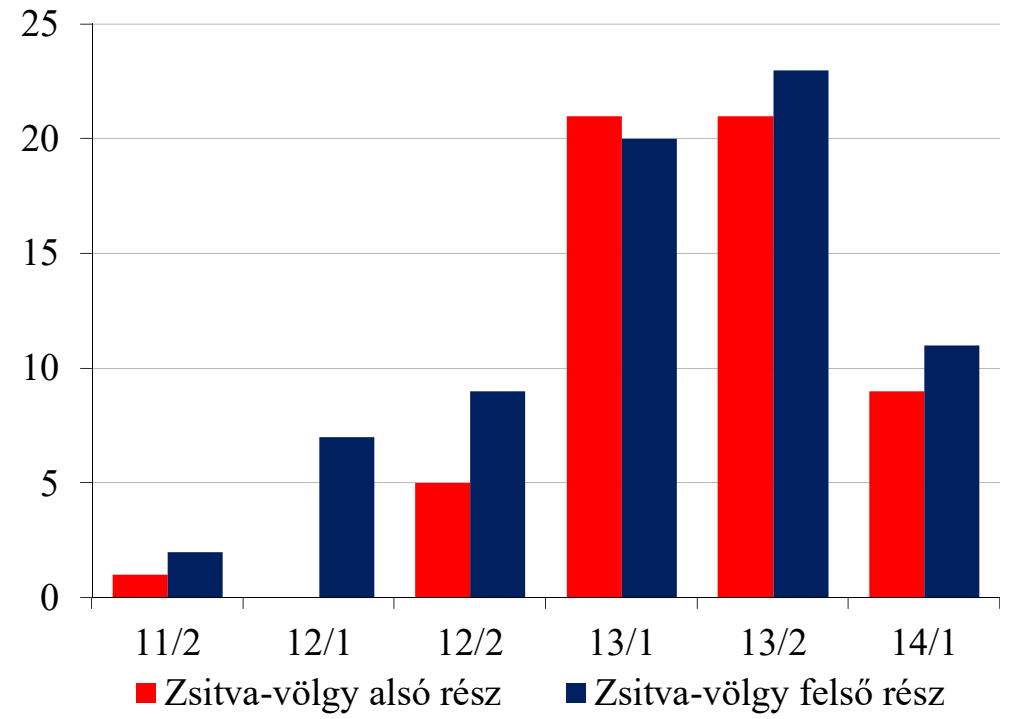

7. ábra. A Zsitva alsó és felsö völgye településnévi adatainak idöbeli megoszlása

Arra a kérdésre, hogy ezek mögött az egyezések és különbözőségek mögött milyen (nyelvi, társadalmi, természeti stb.) tényezők húzódnak meg, jelenleg sajnos nem tudunk választ adni. Mindez pedig jelzi e módszer használatának a jelenlegi korlátait is, azt, hogy egyelöre viszonylag kevés ilyen szempontok szerint elemzett névanyag áll rendelkezésünkre. A relatív kronológia módszere abban az esetben tud kiteljesedni, ha a mainál jóval szélesebb körü lesz az összevetéshez felhasználható anyagok állománya. E vizsgálatok révén egyre több kérdés válik megválaszolhatóvá, de ezzel együtt egyre több, a magyarság múltjával kapcsolatos kérdést is hoz felszínre a kutatás.

\section{Irodalom}

E. ABAFFY ERZSÉBET 2003. Az ómagyar kor. Hangtörténet. In: KISS JENŐ-PUSZTAI FERENC szerk. Magyar nyelvtörténet. Budapest, Osiris Kiadó. 301-351.

ÁSz. = FEHÉRTÓI KATALIN 2004. Árpád-kori személynévtár. 1000-1301. Budapest, Akadémiai Kiadó.

BÁRCZI GÉZA 1958. Magyar hangtörténet. Második, bövített kiadás. Budapest, Tankönyvkiadó.

BÉNYEI ÁGNES 2012. Helynévképzés a magyarban. A Magyar Névarchívum Kiadványai 26. Debrecen, Debreceni Egyetemi Kiadó.

DHA. = Diplomata Hungariae Antiquissima. Vol. I. Redidit GYÖRFFY GYÖRGY. Budapest, 1992. 
FNESz. = KISS LAJOS 1988. Földrajzi nevek etimológiai szótára I-II. Negyedik, bövített és javított kiadás. Budapest, Akadémiai Kiadó.

Gerstner KÁROly 2018. Hangtörténet. In: Kiss JenÖ-PuszTAi FerenC szerk. $A$ magyar nyelvtörténet kézikönyve. Budapest, Tinta Könyvkiadó. 103-128.

Gy. = GYÖRFFY GYÖRGY 1963-1998. Az Árpád-kori Magyarország történeti földrajza 1-4. Budapest, Akadémiai Kiadó.

GYÖRFFY ERZSÉBET 2011. Korai ómagyar kori folyóvíznevek. A Magyar Névarchívum Kiadványai 20. Debrecen, Debreceni Egyetemi Kiadó.

HA. = HOFFMANN ISTVÁN-RÁCZ ANITA-TÓTH VALÉRIA 1997, 1999, 2012, 2017. Helynévtörténeti adatok a korai ómagyar korból. 1. Abaúj-Csongrád vármegye. 2. Doboka-Györ vármegye. 3. Heves-Küküllö vármegye. 4. Liptó-Pilis vármegye. Debrecen, Debreceni Egyetemi Kiadó.

HOFFMANN ISTVÁN 2004. Az oklevelek helynévi szórványainak nyelvi hátteréröl. Helynévtörténeti Tanulmányok 1: 9-61.

HofFMANN IsTVÁN 2010. A Tihanyi alapitólevél mint helynévtörténeti forrás. A Magyar Névarchívum Kiadványai 16. Debrecen, Debreceni Egyetemi Kiadó.

HOFFMANN ISTVÁN 2017a. Víznevek és településnevek etnikumtörténeti tanulságai. Történeti Földrajzi Közlemények 5: 47-61.

HOFFMANN ISTVÁN 2017b. A Bakonyalja etnikai viszonyai a honfoglalást követő évszázadokban. In: HAJBA RENÁTA-TÓTH PÉTER-VÖRÖS FERENC szerk. ,, ...ahogy a csillag megy az égen ...". Köszöntö kötet Molnár Zoltán tiszteletére. Szombathely, Savaria University Press. 137-150.

HofFMANN ISTVÁN 2019. Magyar-szláv helynévmintázatok az ómagyar kori Bakonyalján. Magyar Nyelvjárások 57: 5-29.

HOFFMANN ISTVÁN-RÁCZ ANITA-TÓTH VALÉRIA 2018. Régi magyar helynévadás. A korai ómagyar kor helynevei mint a magyar nyelvtörténet forrásai. Budapest, Gondolat Kiadó.

HOFFMANN IsTVÁN-TÓTH VALÉRIA 2016. A nyelvi és az etnikai rekonstrukció kérdései a 11. századi Kárpát-medencében. Századok 150: 257-318.

KÁZMÉR MiKLÓs 1970. A »falu« a magyar helynevekben. XIII-XIX. század. Budapest, Akadémiai Kiadó.

KENYHERCZ RÓBERT 2013. A szókezdő mássalhangzó-torlódások az ómagyar korban. A helynevek hangtörténeti forrásértéke. A Magyar Névarchívum Kiadványai 28. Debrecen, Debreceni Egyetemi Kiadó.

KENYHERCZ RÓBERT 2014. A szláv helynévformánsok kölcsönzéséröl. Az -óc végü helynevek a magyarban. Nyelvtudományi Közlemények 110: 205-226.

KISS LAJOS 1988. Magyarország földrajzi és társadalmi arculata az Árpád-korban. Magyar Nyelv 84: 129-155.

KISS LAJOS 1999. Történeti vizsgálatok a földrajzi nevek körében. Piliscsaba, Pázmány Péter Katolikus Egyetem.

KMHsz. = HoFFMANN ISTVÁN szerk. 2005. Korai magyar helynévszótár 1000-1350. I. Abaúj-Csongrád vármegye. A Magyar Névarchívum Kiadványai 10. Debrecen, Debreceni Egyetem Magyar Nyelvtudományi Tanszéke. 
KNIEZSA ISTVÁN 1938. Magyarország népei a XI.-ik században. In: SERÉDI JUSZTINIÁN szerk. Emlékkönyv Szent István király halálának kilencszázadik évfordulóján. Budapest, Magyar Tudományos Akadémia. II, 365-472.

KNIEZSA ISTVÁN 1947-1949. A zobori apátság 1111. és 1113. évi oklevelei, mint nyelvi (nyelvjárási) emlékek. Magyar Népnyelv 6: 3-50.

KNIEZSA ISTVÁN 1955/1974. A magyar nyelv szláv jövevényszavai I/1-2. 2. kiadás. Budapest, Akadémiai Kiadó.

KovÁCs Helga 2014. Az Örs helynevek etimológiájáról. Helynévtörténeti Tanulmányok 10: 19-32.

KovÁCs Éva 2015. A Tihanyi összeírás mint helynévtörténeti forrás. A Magyar Névarchívum Kiadványai 34. Debrecen, Debreceni Egyetemi Kiadó.

KRISTÓ GYULA 2003. Nem magyar népek a középkori Magyarországon. Budapest, Lucidus Kiadó.

$\mathrm{K} 1$ = A második katonai felmérés térképe.

https://mapire.eu/en/map/europe-19century-

secondsurvey/?layers $=158 \% 2 \mathrm{C} 164 \&$ bbox $=-$

436646.4064000179\%2C5300039.607545369\%2C4538486.890625535\%2C652 3032.0601081895

K2 = Az első katonai felmérés térképe.

https://mapire.eu/en/map/europe-

18 centuryfirstsurvey/?layers $=163 \% 2 \mathrm{C} 165 \& b b o x=324505.06467862194 \% 2 \mathrm{C} 53$

69979.687913253\%2C5299638.361704174\%2C6592972.140476073

LIPSZKY, JOANNES 1806. Mappa generalis regni Hungariae. Pesthini.

MELICH JÁNOS 1925-1929. A honfoglaláskori Magyarország. Budapest, Akadémiai Kiadó.

NYIRKOS ISTVÁN 1987. Az inetimologikus mássalhangzók a magyarban. Debrecen, Kossuth Lajos Tudományegyetem Magyar Nyelvtudományi Intézet.

NYIRKOS ISTVÁN 1993. Az inetimologikus magánhangzók a magyarban. Debrecen, Kossuth Lajos Tudományegyetem Magyar Nyelvtudományi Intézet.

Póczos Rita 2001. Az Árpád-kori Borsod és Bodrog vármegye településneveinek nyelvészeti elemzése. A Magyar Névarchívum Kiadványai 5. Debrecen, Debreceni Egyetem Magyar Nyelvtudományi Tanszék.

RÁCZ ANITA 2011. Adatok a népnévvel alakult régi településneveink történetéhez. A Magyar Névarchívum Kiadványai 19. Debrecen, Debreceni Egyetemi Kiadó.

RÁCZ ANITA 2016. Etnonimák a régi magyar településnevekben. A Magyar Névarchívum Kiadványai 37. Debrecen, Debreceni Egyetemi Kiadó.

SLÍZ MARIANN 2011. Anjou-kori személynévtár 1301-1342. Budapest, Históriaantik. SLíz MARIANN 2017. Anjou-kori személynévtár 1343-1359. Budapest, Magyar Nyelvtudományi Társaság.

ŠMILAUER, VLADIMÍR 1932. Vodopis starého Slovenska. Praha-Bratislava.

ŠMILAUER, VLADIMÍR 1970. Príručka slovanské Toponomastiky. Handbuch der slawischen Toponomastik. Praha, Academia. 
SzÖKE MELINDA 2015. A garamszentbenedeki apátság alapitólevelének nyelvtörténeti vizsgálata. A Magyar Névarchívum Kiadványai 33. Debrecen, Debreceni Egyetemi Kiadó.

TESz. = BENKÖ LORÁND föszerk. 1967-1976. A magyar nyelv történeti-etimológiai szótára 1-3. Budapest, Akadémiai Kiadó.

TÓTH VALÉRIA 2001a. Az Árpád kori Abaúj és Bars vármegye helyneveinek történetietimológiai szótára. A Magyar Névarchívum Kiadványai 4. Debrecen, Debreceni Egyetem Magyar Nyelvtudományi Tanszék.

TÓTH VALÉRIA 2001b. Az Árpád kori Abaúj és Bars vármegye helyneveinek történetietimológiai szótára. A Magyar Névarchívum Kiadványai 4. Debrecen, Debreceni Egyetem Magyar Nyelvtudományi Tanszék.

TÓTH VALÉRIA 2008. Településnevek változástipológiája. A Magyar Névarchívum Kiadványai 14. Debrecen, Debreceni Egyetem Magyar Nyelvtudományi Tanszéke.

TÓTH VALÉRIA 2016. Személynévadás és személynévhasználat az ómagyar korban. A Magyar Névarchívum Kiadványai 38. Debrecen, Debreceni Egyetemi Kiadó.

TÓTH VALÉRIA 2019. Módszertani problémák a Kárpát-medence régi helyneveinek etimológiai kutatásában. Helynévtörténeti Tanulmányok 15: 21-48.

VARSIK, BRONISLAV 1990. Slovanské (slovenské) názvy riek na Slovensku a ich prevzatie Mad'armi v 10.-12. storočí. Bratislava, Vydatel'stvo Slovenskej Akadémie Vied.

ZOLTÁN ANDRÁS 2015. Szláv-magyar nyelvi kapcsolatok a 11. században. Helynévtörténeti Tanulmányok 11: 35-44.

\section{Toponym Patterns in the Zsitva (Žitava) Valley during the Old Hungarian Era}

The paper undertakes to clarify the linguistic relations of the Zsitva valley (a former tributary of the Danube, today that of Nyitra) during the early Old Hungarian Era (between 895 and 1350). This is necessary because we have only limited knowledge in this respect and what is more, it is based on theories and methods developed in the first half of the $20^{\text {th }}$ century that have become outdated in this scholarly field. Thus the results of this study are important not only for the area under scrutiny but also from the perspective of developing new methods.

This approach proposes to use toponym reconstruction instead of toponym etymology as a methodological principle, which studies the name not only at its origin but analyzes it within a more complex system of relationships. Instead of an absolute chronology, a relative chronology is used in the analysis, which studies the circumstances of genesis and changes within the relationship of names to each other. At the same time, it wishes to involve the complete toponymic corpus of an era with a broader time frame.

The analysis presents different toponym patterns in the lower and upper regions of the Zsitva, in harmony with the differences in natural geography and 
settlement history. In the lower valley of the river, besides the hydronym of a Slavic origin, we may find only settlement names and microtoponyms deriving from Hungarian, similarly to a study conducted in the Bakonyalja region, however, with a different historical background: in that case it has been proven that the Hungarians settled over the Slavs, while this is not an option here.

The name of the river could have been created in the upper valley of the Zsitva where settlement names of a Slavic origin can be found. It was in this area that Hungarians could have met the Slavs for the first time, with whom they lived together in the era under scrutiny, and in this process they also borrowed their river names and settlement names. The adaptation of the names into Hungarian is well indicated by the linguistic forms of the survived records. The analysis provides insights into this linguistic interaction as well as the Hungarian and Slavic settlement process. The typological comparison of the Hungarian toponymic corpus of the two areas indicates that the toponym pattern of the lower river valley is of a more archaic type than that of the upper valley of the Zsitva.

The received results and the applied methods may be refined further by similar analyses carried out in other regions, as well as their comparison with the contemporary archeological culture of the areas in question. 